\title{
METAFORY MIŁOŚCI \\ W PORTRECIE PATRYCJUSZKI GDAŃSKIEJ ANTONA MÖLLERA
}

Portret patrycjuszki gdańskiej, dawniej przypisywany Antonowi Möllerowi Starszemu (ok. 1563-1611) (Gyssling; THIEME BeCKer t. 25, 4-5; Drost; Mosingiewicz 44-52; Grzybkowska, Złoty 96-97; Harasymowicz, „Anton” 339-358; Labuda, „Gdańsk” 261-274), z Muzeum Narodowego w Gdańsku (MNG), datowany przez Aleksandrę Jaśniewicz na 1598 r. („Małżeństwo” 8-9; Portret 453), należy do najbardziej znanych dzieł sztuki gdańskiej. Budzi jednak do dziś spory atrybucyjne ${ }^{1}$, nie ustalono także tożsamości portretowanej (Grzybkowska, Złoty 97, il. 124; Aurea Porta Rzeczypospolitej t. 1, nota: Cieślak 116; nota: Górecka-Petrajtis 176). Przedstawia elegancką kobietę bez oznak emocji (il. 1a) ${ }^{2}$. Artysta sportretował ją w ujęciu do kolan, w czerwonej sukni i śnieżnobiałej krezie. Suknia łączy elementy mody hisz-

Dr Beata Purc-Stępniak - Uniwersytet Gdański, Wydział Historyczny, Instytut Historii Sztuki, Zakład Teorii Sztuki oraz Muzeum Narodowe w Gdańsku, Pracownia Malarstwa Europejskiego; e-mail: beata.purc-stepniak@ug.edu.pl; ORCID: https://orcid.org/0000-0003-1026-5574.

${ }^{1}$ Pod koniec lat 30. XX wieku portret był wiązany z twórczością Geerta Jantzena: (Drost 120), po 1945 r. z warsztatem Antona Möllera (Gosieniecka, Malarstwo Gdańskie 17, 54, kat. Nr. 49; Grzybowska, Zloty 96-97, il. VII, 123; Leonardo da Vinci, nota: Górecka-Petrajtis 98-99, kat. Nr. 201; Stownik Biograficzny Pomorza t. 1, 49; t. 3. 97; Aurea Porta Rzeczypospolitej t. II, 167, 126, il. 8; Chodyński, De gustibus 173; Tylicki, „Herman Han, Holender” 182; Jaśniewicz, Portret gdańskiej patrycjuszki (nota katalogowa), w: Amor Polonus 124, il. s. 125; Jaśniewicz, Portret, 453 lub samym Möllerem; (Drost 120 i Tafel 63; Aurea Porta Rzeczypospolitej. Katalog, t. 1, 167). Tylicki przypisuje portret Geertowi Janssenowi in den Enge (Tylicki, „Malarstwo i rysunek” 312; „Herman Han - dwa oblicza artysty” 55-73; 192).

${ }^{2}$ Obraz na desce dębowej, technika mieszana (olej, tempera), $103 \times 80 \mathrm{~cm}, \mathrm{nr} \mathrm{MNG} / \mathrm{SD} /$ 287/M. Zapisany jako „Damenbildnis” von 1598, dar do zbiorów Stadtmuseum Danzig w $1931 \mathrm{r}$. od kupca Alberta Müncha z Gdańska, zam. przy Szerokiej 51/52: APG. 1384/21, Geschenke (1914-1944), s. 74, Herrn A. Münch, Danzig, Breitgasse 51 das Stadtmuseum. 1 Gemälde „Damenbildnis" von 1598 G 2200 Betrag von Guden 2200. erhalten: Danzig, den 9.03.1931. Informacje zawdzięczam pani Helenie Kowalskiej (MNG). 
pańskiej i niemieckiej, figurę podkreśla gors ozdobiony podwójnym złotym łańcuchem. Bransolety o pancerzowym splocie (manele), które zdobią nadgarstki patrycjuszki, znamy z portretów niderlandzkich, angielskich i niemieckich XVI wieku' ${ }^{3}$. Podobnie jak zawieszany u pasa pommander, czyli pojemnik na wonności (Meininghauss 2220-2221). Na wysokości bioder kobieta prezentuje trzymany $\mathrm{w}$ dłoni trudny do rozpoznania owoc, drugą ręką dotyka łańcucha lub wskazuje na łono (Jaśniewicz, „Małżeństwo” 8). Podobna poza portretowa utrzymywała się w malarstwie flamandzkim i holenderskim do lat 20. XVII wieku ${ }^{4}$. Typowymi elementami stroju gdańskiego są tu czepiec wysadzany perłami i plisowany biały fartuch (Rembowska 50; Mielnik, „Stateczne matrony” 25, 34, 37, 38; il. 3; 8; 9; Kizik, „Ubiory” 22). Ten strój wystąpił w gdańskim malarstwie epitafijnym (por. epitafium Michała Loitza, (1561-64), Gdańsk, kościół NMP; Epitafium obrazowe Bartłomieja Wagnera (1571-75), Gdańsk, kościół NMP; epitafium Jana Hutzinga, 1584-1594, Gdańsk, kościół św. Jana: Cieślak il. 6, 10, 17) . Möller utrwalił go na swoich rysunkach. Wedle nich w $1601 \mathrm{r}$. wykonano drzeworyty przedstawiające gdańskie stroje kobiece Omnium Statuum Foemini sexus ornatu ${ }^{6}$. Taki strój pojawia się na kilku obrazach Möllera: Zabawa w gdańskim domu patrycjuszowskim (ok. 1600) (Tylicki, Rysunek gdański 42), Alegoria cnoty matżeńskiej (ok.1600) (il. 2a); (Jaśniewicz, Portret 400-401) oraz na Portrecie patrycjuszki z 1608 r. (Rohde 13). W takim stroju ukazano kobietę z rodziny Henningów w epitafium tej rodziny ${ }^{7}$. Teresa Grzybkowska rozpoznała konterfekt jako „patrycjuszowską Wenus” (Złoty 97). Krystyna Górecka-Petrajtis uznała portret za wizerunek przedślubny, a owoc określiła jako granat (Leonardo 98-990). Dla Teresy Labudy wspomniany owoc to jabłko (Labuda, „Portret” 125; Labuda, „Antoni” 159-140), dla Aleksandry Jaś-

\footnotetext{
${ }^{3}$ Na przykład Gortzius Geldorp, Portret Hortensji del Prado, Rijskmuseum, Amsterdam. Por. Kluczwajd, Skarb ze Skrywilna 98-103.

${ }^{4} \mathrm{Na}$ przykład Cornelis van der Voort (ok. 1576-1624), Portret młodej kobiety, 1622; Cornelis de Vos, Portret kobiety; Frans Hals, Portret kobiety, ok. 1611, Chatsworth, Chatsworth House; Frans Hals, Portret Anetty Hanemans, 1625. Zob. Köhler 61-69; Schaumann 28-33; Falke 129; Dülmen 75.

${ }^{5}$ Por. epitafium Michała Loitza, (1561-64), Gdańsk, kościół NMP; Epitafium obrazowe Bartłomieja Wagnera (1571-75), Gdańsk, kościół NMP.; epitafium Jana Hutzinga, 1584-1594, Gdańsk, kościół św. Jana. Cieślak, Kościót, il. 6, 10, 17.

${ }^{6}$ Bertling 1-14; Drzeworyt z serii Danziger frauentrachtbuch, 1601 (Górski Wacłw, Anton Möller, Fashionable Marriage dress, drzeworyt z serii Danziger frauentrachtenbuch, 1601). Por. repr. Tylicki, „Obraz Alegoria” 49, il. 19; Mielnik, Tematyka, 129; Kizik, Wesele 14 oraz Ubiory 18.

${ }^{7}$ Herman Han (?), Epitafium rodziny Henning, pochodzi z kościoła św. Katarzyny w Gdańsku, MNG.
} 
niewicz to pigwa, a kobieta jest w odmiennym stanie (Jaśniewicz, „Małżenstwo" 9).

Na ramie portretu gdańskiej patrycjuszki widnieje napis: „1598 AETATIS SUAE 18". Sprawdzając genealogie gdańskich rodów mieszczańskich, trudno wskazać niewiastę, która odpowiadałaby wiekowi portretowanej podanemu na ramie obrazu (Patrizer; Zdrenka 1526-1792). Rama nie jest oryginalna, została dodana $\mathrm{w}$ trakcie użytkowania obrazu. Podobną kobietę ukazano w portrecie znajdującym się na Wawelu ${ }^{8}$. Wydaje się jednak, że istotny w identyfikacji patrycjuszki jest obraz stanowiący wieko instrumentu muzycznego: Alegoria cnoty matżeńskiej, ok. 1600. Przez Tylickiego przypisany Hermanowi Hanowi Młodszemu'. Labuda na podstawie artykułu Tylickiego z 1997 r., omawiającego Alegorię cnoty matżeńskiej, sądzi, że portretowaną jest Agathe, córka burmistrza Johanna von der Linde ${ }^{10}$. Helena Kowalska dostrzega podobieństwo niewiasty z Portretu patrycjuszki z młodą kobietą w Alegorii cnoty matżeńskiej, a autorstwo Alegorii wiąże z Antonem Möllerem. Sądzi, że Alegoria cnoty matżeńskiej nie dotyczy rodziny von der Linde, lecz Speymann (Speimann), co uwiarygodnia rozpoznaniem kluczowych postaci w scenie głównej (Kowalska 147-162).

Alegoria upamiętniałaby ślub Johanna Speymanna (1563-1623), burmistrza gdańskiego, burgrabiego królewskiego, kolekcjonera i mecenasa sztuki, zawarty w 1596 r. z Marią Judytą z Bahrów, która wychowywała się na dworze Anny Habsburżanki. Młoda para siedzi pod baldachimem łoża małżeńskiego. W starszym mężczyźnie z brodą, siedzącym jako ostatni po lewej stronie obrazu (od strony widza), Kowalska dostrzega Szymona Bahra, faktora królewskiego. Mężczyzna z pucharem obok niego to król Zygmunt III Waza - jedyny z nakryciem głowy (mimo że król nie był obecny na zaślubinach, został przedstawiony - tak podkreślono związki z rodziną królewską). Pierwsza para z prawej strony obrazu to przyjaciel Speymanna Bartholomäus Schachmann (1559-1614), według Kowalskiej ze swoją pierwszą żoną Katarzyną. Można zgodzić się z wyżej przedstawioną identyfikacją

${ }^{8}$ Dawniej: warsztat Möllera (obecnie przypisany Hermanowi Hanowi), Jaśniewicz, Portret, 421, Zamek Królewski na Wawelu, Nr. inw. Dep. 7, technika mieszana, 50,8 ×41, 5 cm; Nowacki $45-46$

${ }^{9}$ Rozpoznany jako „Alegoria małżeństwa Agaty von der Linde” z powodu drzewa lipy, pod którym siedzi para: Tylicki, Obraz „Alegoria, 41-58; Tylicki, „Herman Han, Holender z Gdańska”201-204; Tylicki, „Herman Han” 56-57; 187-192; Tylicki, „Malarstwo” 309-370; 315-316 oraz Tylicki, „Möller” 132-133; Tylicki, „Han”32-133; por. inne stanowisko: Aurea Porta Rzeczypospolitej, 185-186, nota oprac. przez Morkę oraz Morka, „Kilka uwag” 250-269.

${ }^{10}$ Labuda, „Antoni” 139-140; z tą sugestią nie zgadza się Tylicki, Herman Han - Katalog, 186; 190; 192 
rodzin, z zastrzeżeniem jednak, jeśli przyjąć datowanie obrazu przez Tylickiego na ok. 1600 r., że przedstawiona jest nie pierwsza, a druga żona Schachmanna - poślubiona 9 października 1600 r. Anna Blömcke (ok.15701625) (Nowak 3). Jest to zachęcające do dalszych badań rozpoznanie, wiadomo bowiem, że obu patrycjuszy łączyła przyjaźń oraz zainteresowania kolekcjonerstwem i sztuką. Chociaż typy twarzy postaci w obrazie są konwencjonalne, to styl ubiorów i przedstawione atrybuty świadczą o chęci symbolicznego zapisania historycznych wydarzeń i relacji. Ponadto zastosowana we wspomnianej alegorii ikonografia łączy się $\mathrm{z}$ grupą portretów wykonanych w warsztacie Möllera powstałych pod koniec lat 90. XVI wieku, w których występuje podwieszona kotara z węzłem. W Alegorii cnoty małżeńskiej nad łożem $\mathrm{z}$ baldachimem jest rozpięta tkanina podwieszona w dwóch miejscach na konarach drzew przyjmujących kształt litery Y: po lewej stronie obrazu nad parą w żółtych strojach przy Szymonie Bahrze i nad Schachmannem z żoną (Zdrenka 273). Ten ikonograficzny motyw, znany ze sztuki włoskiej, jest w podjętych poniżej rozważaniach nad portretem ważną informacją, dotyczącą symboliki szczęścia w miłości ${ }^{11}$.

$\mathrm{Na}$ Portrecie patrycjuszki z MNG wiązanej z Möllerem była pierwotnie przedstawiona kotara zaopatrzona $\mathrm{w}$ dwa węzły po bokach. Ujawniła to fotografia w świetle podczerwonym IR (il. 3b). Obecnie są one zamalowane. Układ tkaniny jest podobny do kotary z Portretu nieznanej patrycjuszki Antona Möllera Starszego (ok. 1590) z niemieckiej kolekcji prywatnej w Kolonii (il. 7a) ${ }^{12}$. W konterfekcie gdańskiej patrycjuszki z MNG próba zlikwidowania sfałdowań kotary w obrazie mogła być dokonana w XIX wieku przez kolejnego posiadacza portretu. Ślad owego zamalowania jest widoczny już na fotografii portretu z $1938 \mathrm{r}$. W miejscu węzłów znajdują się czarne plamy, w oświetleniu bocznym jednak obserwujemy z lewej strony sfałdowaną tkaninę obszytą lamówką. Z prawej strony widoczne jest przewiązanie tkaniny taśmą z kokardą (il. 3a). Dukt prowadzenia pędzla imituje ułożenie węzła kotary. Lepiej go widać w oświetleniu białym bocznym, także w promieniach UV. Sposób malowania zasłony z węzłem w Portrecie patrycjuszki z MNG przypomina zasłonę w Antona Möllera (?) Portrecie chtopca ze szczygłem z muzeum w Gliwicach (il. 1b). W 1997 r .w pracowni

${ }^{11}$ Znak Y jako dobry wybór, w Geofroy Torys, wyd. 1529, Londyn, National Gallery, według Friedrich, Abb.10, 384.

${ }^{12}$ Od lat 20. XX wieku obraz w kolekcji Heinricha Neuerburga w Kolonii (Jaśniewicz, „Małżeństwo" 7-8; Portret 451 - tu literatura). W 1952 r. wymieniany jako obraz A. Möllera, olej, deska, wym. $90 \times 67 \mathrm{~cm}$, należał do kolońskiej kolekcji prywatnej. Portret oferowany do sprzedaży w domu aukcyjnym Lempertz w 2017 r., a w 2018 r. do zakupu przez MNG. 
konserwatorskiej MNG zdjęto werniks w najjaśniejszych partiach stroju oraz $\mathrm{z}$ twarzy i rąk patrycjuszki ${ }^{13}$. Uwidoczniły się wówczas punktowania wykonane wcześniej na twarzy modela, w partii kołnierza, wzdłuż krawędzi i na łączeniach desek w górnej części obrazu. Na fotografii IR widać zarys węzła na kotarze w lewym i prawym, górnym rogu obrazu (il. 3 b). Ten ikonograficzny szczegół nie został zauważony przez badaczy. Nie interesowano się nim w semantyce portretu, wystąpił jednak w siedmiu zachowanych do dziś, a malowanych przez Antona Möllera i jego warsztat portretach kobiet, mężczyzn i dzieci: Anton Möller (?), Portret chłopca ze szczyglem (1596 r., Muzeum w Gliwicach) (il. 1b); Portret biskupa Moritza Ferbera (ok. 1590, olej, deska, sygn. AM. 1590 - kopia z obrazu Crispina Herranta autoryzowana przez Möllera) (il. 7d); Portret starszej patrycjuszki (ok. 1600, Lwowska Galeria Obrazów) (il. 7b); Anton Möller, Portret nieznanej patrycjuszki (ok. 1590, kolekcja prywatna, Kolonia) (il. 7a); Anton Möller, krąg, Portret patrycjuszki (ok. 1590-1600, Muzeum Narodowe Finlandii) (il. 7c) ${ }^{14}$; Anton Möller, warsztat, Portret Barttomieja Schachmanna (ok. 1606, Biblioteka Gdańska PAN) (i1. 4a); Portret patrycjuszki gdańskiej (1599, MNG) (il. 1a).

Niniejszy artykuł poddaje analizie wybraną dla omawianej portretowanej patrycjuszki konwencję obrazową uwzględniającą kotarę, zastosowane atrybuty i ubiór. Jest to przyczynek do badań nad portretem prywatnym, który obowiązywał w gdańskiej sztuce pod wpływem mody panującej w XVI-wiecznym malarstwie europejskim. Analiza konterfektu staje się okazją do zastanowienia się nad ikonograficznymi źródłami portretu w Gdańsku na przykładzie twórczości Möllera i jego warsztatu w kontekście europejskiego malarstwa portretowego.

W malarstwie XVI wieku można wyodrębnić grupę obrazów, w których występowała kotara zawiązana w węzeł. Przykłady odnajdujemy w dziełach włoskich, niderlandzkich, angielskich, francuskich, rzadziej niemieckich i hiszpańskich. Takie kotary wystąpiły w portretach uczonych kobiet i mężczyzn, arystokratów włoskich z początku XVI wieku. Następnie dały się zauważyć w portrecie dworskim i bogatego patrycjatu północnoeuropejskiego, w konterfektach osób dorosłych, dzieci, żyjących ${ }^{15}$ i zmarłych ${ }^{16}$. Czy w takim razie węzeł w obrazie jest tylko elementem zdobniczym, czy nośnikiem znaczenia?

${ }^{13}$ Dziękuję konserwator Marzenie Kłosowskiej (MNG) za udostępnienie fotografii w promieniach UV.

${ }^{14}$ Olej, deska, 99×71 cm, Suomen Kansallimuseoon, nr. inw. KM 2287:2: Jaśniewicz, Portret 455 .

${ }^{15}$ Jan Gossaert (aktywny 1503-1532), Dzieci Christiana II króla Danii, 1526, The Royal Collection, London; Anthonie Palamedesz, Portret chłopca z cytryna, Dorotheum 2013.

${ }^{16}$ Na przykład Johannes Thopas, Portret Cathariny Margarethy van Valkenburg (?), 1682, Royal Art Gallery, Mauritshuis Museum, Haga. 
Powróćmy do wspomnianej Alegorii cnoty matżeńskiej z ok. 1600 r., która wypłynęła w handlu dziełami sztuki w latach 90. wieku XX (Galeria Lingenauber, Düsseldorf). Obraz ten uświadamia, jaką na przełomie XVI/ XVII wieku wartość artystyczną i uczuciową miał portret i jakie przyjmował formy, by zadowolić wyszukane gusta wykształconego patrycjatu gdańskiego. Erudycyjne programy tego rodzaju dzieł wespół z artystami tworzyli sami zamawiający. Alegoria cnoty malżeńskiej mogła powstać jako rezultat zrealizowanego pomysłu na upamiętnienie dwu przyjaźniących się rodzin Johanna Speymanna i Bartholomäusa Schachmanna. Być może pierwotnie istniały dwie takie kompozycje $\mathrm{z}$ przeznaczeniem na wieka wirginałów dla dwu rodzin wykonane przez Möllera i Hana. Jeden z obrazów widział w Królewcu w 30. latach XIX wieku Rastawiecki i uznał za pracę Möllera (Rastawiecki 51). Alegoria cnoty matżeńskiej (il. 2 a) wystawiona w Galerie Lingenauber jest bardzo zbieżna z rysunkiem Antona Möllera Święto Wiosny (1596, Kupferstichkabinett, Berlin). Herman Han Młodszy miał wówczas ok. 18 lat - czy dokończył obraz zaczęty przez Möllera, powtórzył go lub stworzył nowy i dał do inskrypcji na obrazie swoje nazwisko, nie wiemy. Stało się to przedmiotem dyskusji (Morka, „Kilka uwag”; Kowalska 152; Pałubicki 282) ${ }^{17}$. Miejmy nadzieję, że badania pomogą wyjaśnić te kwestie.

Pomysł ukazania w Alegorii cnoty malżeńskiej z lewej strony grupy postaci otaczającej Wenus z płonącym sercem zainspirowany został ryciną Jana Saenredama, według Hendrika Goltziusa Wenus i jej dzieci (ok. 1596) (il. 2b), a zatem tytuł obrazu nadany w 1997 r. oddaje tylko cząstkowe jego znaczenie $^{18}$. Winien raczej brzmieć Alegoria miłości lub Zwycięstwo miłości (Victoria amoris), gdyż zawiera aluzje do siły miłości. Nagość personifikacji Wenus oznacza moc przyciągania miłości w różnych jej odmianach, natarczywej zmysłowej, także przyjaźni oraz małżeństwa z jego blaskami i cieniami, w obliczu vanitas i fortitudo (Grabski, „'Victoria Amoris"” 9-33; The Significance 237-264). Był to stary temat Dzieci planety Wenus (Hauber; Strauss 48-54; Mirimonde). Pomysł zaś obrazu jako peanu na cześć związków przyjaźni między grupą światłych przyjaciół patrycjuszy opierał się na jednej z rycin Goltziusa o władzy Wenus, bez której inspiracji nie można wytłumaczyć warstwy ideowej także Portretu patrycjuszki gdańskiej. W latach 90. XVI wieku Goltzius wykonał kilkanaście wyobrażeń Wenus z płonącym

\footnotetext{
${ }^{17}$ Księga chrztów 1580-1589, 10 - data 29 lutego 1580 r. Mielnik (153-156; 231-235) dostrzega w obrazie antytezę miłości cielesnej i chrześcijańskiej małżeńskiej.

${ }^{18}$ Rysunek Antona Möllera Święto Wiosny (1596, Kupferstichkabinett, Berlin) jest inspirowany tą samą ryciną Goltziusa - Wenus i jej dzieci (ok. 1596) (il. 8a).
} 
sercem lub owocem przypominającym jabłko czy pomarańczę. Te koncepty szybko powielono w grafice ${ }^{19}$. Realizacje Alegorii miłości i Portretu patrycjuszki ok. 1600 r. musiały być koncypowane w gronie tych samych ludzi, świadomych związków między poezją, sztukami plastycznymi, religią a filozofią. O przyjaźni między Speymannem i Schachmanem i ich wspólnych działaniach na rzecz miasta napisano już sporo (Pszczółkowska, „Speymann” 247 248). Wypływała ona z umiłowania podobnych gustów artystycznych i sztuki włoskiej, kolekcjonerskiej i bibliofilskiej pasji ${ }^{20}$.

Alegoria miłości i Portret patrycjuszki gdańskiej należą do kultury upamiętnienia (memoria) ważnych momentów życia. Najbliższym Portretu patrycjuszki pod względem formalno-artystycznym i ikonograficznym jest Antona Möllera (?) Portret chtopca ze szczygtem (ok. 1605) (il. 1b), prawdopodobnie syna Schachmanna ${ }^{21}$, na co wskazała Grzybkowska (Zloty 96-97). Potwierdzałby, że w portrecie chłopca kolory stroju i żółto-czarna tonacja obrazu nawiązują do barw tarczy herbowej rodziny Schachmannów (1b). Było to także w zwyczaju w malarstwie portretowym Florencji XVI wieku ${ }^{22}$. To samo dotyczy Portretu patrycjuszki z MNG. Kolory w obrazie są zgodne z barwą herbu Speymann (il. 1b), kotara za plecami jest zielona (Gizowski, $598-599 ; 512-513)$. W obydwu portretach zastosowano ten sam język artystyczny i podobnie namalowano podwiązaną zasłonę. Konterfekt chłopca na ramie nosi datę 1586. Warto zatem w kontekście badania portretu patrycjuszki zwrócić uwagę na portret Bartholomäusa Schachmanna (Anton Möller, warsztat, po 1605, Gdańsk, Biblioteka PAN) z chustką w ręku ${ }^{23}, f a z-$ zoletto, rapierem na tle tkaniny podwiązanej sznurem (il. 4a). Jego geneza odwołuje się do malarstwa weneckiego 1. poł. XVI wieku.

Twórcą portretu z przewiązaną sznurem kotarą i chustą w ręku modela był Lorenzo Lotto, np. Portret mężczyzny (1542-1544, New Orlean, New Oreleans Museum of Art) (il. 4b) (Lorenzo Lotto 295-297). Lotto to pierwszy nowoczesny portrecista. Potrafił oddać psychologiczną głębię modela atrybutem

${ }^{19}$ Na przykład Hendrick Goltzius, Wenus z jabłkiem, rysunek 1597, Staatlichen Museen, Berlin; Wenus i Kupidyn, miedzioryt 1595; Jan Saenredam według Goltzius, Wenus i Kupidyn, ok. 1595, miedzioryt; Jacob Matham, Wenus i Kupidyn, 1612. Pomysł jednak takiej prezentacji bogini dał w 1518 r. Baldassare Peruzzi na fresku w willi Ghigi (Farnezina) w Rzymie.

${ }^{20}$ Wpis J. Speymanna znajduje się w sztambuchu B. Schachmanna (Gosieniecka 76).

${ }^{21}$ Syn z drugiego małżeństwa B. Schachmanna z Anną Blömcke $(† 1625)$ - Bartholomäus (II), ur. 17 sierpnia 1601 r. (Patrizer 435).

${ }^{22}$ Na przykład Angolo Bronzino, Portret Ludovico Capponi, 1550-55, New York, Kolekcja Frick (il. 6 a ). Por. Gizowski 598-599; 512-513.

${ }^{23}$ Znaczenie chustki jako mappa, być może zapożyczone z drzeworytu przedstawiającego Jana Bernarda Bonifacio markiza Orii z 1598, omówiła Grzybkowska (Zloty 99). 
koncypowanym ze zwykłych przedmiotów otaczających portretowanego ${ }^{24}$. Ten rodzaj konterfektu mieścił się jednocześnie w formule malarstwa niemieckiego wypracowanego przez Albrechta Dürera i Hansa Holbeina. Należał on do nurtu portretu prywatnego, którego normy efektywnej komunikacji wizualnej zdefiniowano we włoskiej teorii sztuki. Odnosiły się one do formuły znanej od starożytności pod nazwą amphibolia (Kohlenberger 802-806; Ullrich 1514-1519; Bauer, Knape, Koch i Winkler 7-75; Frauke i Kammer 7-30; 242). W niej zamierzoną wieloznaczność portretu uznawano za zaletę. Artyści rozmyślnie tworzyli skromny dobór atrybutów charakteryzujących modela w taki sposób, by był dwuznaczny w odbiorze i tworzył atmosferę intelektualnej elegancji. Mogło się to podobać zwłaszcza przybyszom z Gdańska.

Wiadomo, że Schachmann i Speymann byli w Wenecji dłuższy czas, Speymann oglądał kolekcje sztuki i dokonał pierwszych zakupów (Dzienis 220-222; Karpowicz 185-189). Mógł zapoznać się z typem portretu weneckiego, w którym była obecna podwiązana sznurem kotara ${ }^{25}$. Obaj burmistrzowie byli znawcami sztuki i reprezentowali styl arystokratycznego kolekcjonerstwa znanego $\mathrm{z}$ Italii. Gdańsk w tamtym okresie pełnił także rolę ważnego ośrodka transmisyjnego kultury (Żygulski, „Stary” 11-13). Gościł w nim Giovanni Bernardino Bonifacio, markiz d'Ori (1517-97), z którym przyjaźnił się Schachmannem. Ten włoski humanista przywiózł z sobą do Gdańska księgozbiór i wiedzę o kulturze Wenecji. Johannes Speymann odbył co najmniej dwie morskie podróże z ładunkiem zboża do Italii. Pierwsza, do Livorno, miała miejsce w 1591 r., ładunek zboża dotarł również do Watykanu. Speymann spotkał się wówczas z Ferdynandem I de Medici. W drugiej podróży w 1592 r. zawitał do Rzymu, Genui i Livorno, a w 1593 r. dotarł do papieża. To wtedy odwiedził Wenecję oraz ponownie Florencję (Pszczółkowska, „Speymen” 80). We Florencji zapoznał się z medycejską galerią malarstwa. Posiadł świetną orientację artystyczną. W Gdańsku swoje zainteresowania sztuką Speymann uzewnętrzniał we współpracy z Schachmannem nad projektami upiększenia gmachów użyteczności publicznej (Pszczółkowska, „Speymann” 247-248). Tym bardziej identyfikacja tych dwóch mężczyzn

${ }^{24} \mathrm{~W}$ stylu jego portretów widać wpływy malarzy niemieckich - Dürera, Grünewalda, Holbeina Starszego (Kathke 59-88).

${ }^{25}$ Stosowanie tego motywu wywodzi się ze starożytnej tradycji baldachimu, honorowego wyróżnienia, ozdobionego nodus Heracliteus, podkreślającego siłę i szczęście w odwołaniu do mężności i roztropności Herkulesa. Węzeł heraklitejski wszedł także jako element symboliczny, przypominający zawiązanie skóry lwa, jakie nosił mitologiczny Herkules, do ozdoby płaszcza spinanego na ramieniu w armii rzymskiej paludamentum. W samym jednak płaszczu trudno szukać genezy baldachimu, jak pisze - przy okazji omawiania portretu Schachmanna - Kaleciński (138, przyp. 87). 
w obrazie Alegoria cnoty matżeńskiej ok. 1600 dokonana przez Kowalską wydaje się zasadna.

Speymann był człowiekiem energicznym, posiadającym humanistyczne pasje, które wprowadzał do swoich fundacji w duchu uczonego włoskiego manieryzmu (Grzybkowska, „Mit” 7-9; 39-49; 41-43; Kaleciński, Mity 139; $167-$ $168 ; 233$; 244-250; 207-309). Jako rajca i burmistrz przyczynił się do wzmożonego protektoratu nad artystami ${ }^{26}$, znane są jego kontakty $\mathrm{z}$ Antonem Möllerem. Cenna kolekcja obrazów przywiezionych z Włoch oraz księgozbiór i mediolańskie zbroje czyniły go wiarygodnym kolekcjonerem. Jego wpływowa rola w Gdańsku dała się zauważyć już w 1596 r., gdy ożenił się z Marią Judytą ${ }^{27}$, córką starosty berwałdzkiego Szymona Bahra, herbu Rawicz, zaufanego kupca i bankiera króla szwedzkiego Jana III oraz polskiego króla Zygmunta III Wazy i Katarzyny Jagiellonki (Groth 54). Speymann był kilkakrotnie malowany, m.in. przez Möllera, pomagał mu także zdobyć zamówienia. Około 1600 r. Möller malował dla Speymanna, a jak pamiętamy w Portrecie patrycjuszki dominują barwy herbu Speymann (biel, czerwień, zieleń). Na konterfekcie mogła być w tym czasie przedstawiona jedynie żona Speymanna Maria Judyta. Natomiast akcentowanie w tym portrecie kotary wskazuje na inspirację sztuką włoską. To Speymann i Schachmann mogli przywieźć do miasta wiedzę o portrecie modnym w kręgach Angola Bronzino, Allesandra Alloriego, Lorenzo Lotto. Schachmann zamówił dla siebie portret $\mathrm{z}$ przewiązaną kotarą na wzór tych, jakie widział w Wenecji, jak np. wspomniany już Portret mężczyzny Lorenzo Lotto (il. $4 \mathrm{~b})^{28}$.

Gdańscy kupcy chętnie przywozili z Wenecji przewodniki po mieście i książki poświęcone ubiorom. Do dzisiaj w Bibliotece Gdańskiej PAN są tego typu wydawnictwa ${ }^{29}$. Ryciny do nich przedstawiały kobiety i mężczyzn w całej postaci w różnorodnych strojach, w zależności od stanu. Taki zbiór niewątpliwie musiał mieć w ręku Möller, albowiem na jednej z rycin w książce wydanej w 1591 r., a dotyczącej ubiorów jest prezentowana kobieta pod podwieszoną kotarą zawiązaną w węzeł (il. $5 \mathrm{a})^{30}$.

${ }^{26}$ Przyjaźnił się z Antonem Möllerem, Izaakiem i Wilhelmem van den Blockiem, Janem Strakowskim.

${ }^{27}$ Judith von Bahr $(\dagger 31.01 .1625)$, ślub z Johannen Speymanem odbył się 29 lipca 1596 r. (Patrizer 8).

${ }^{28}$ Portret znajdował się do XIX wieku w weneckiej kolekcji Giovanelli.

${ }^{29}$ Cesare Vecellio, Degli habiti antichi, Wenecja $1590\left(\mathrm{Ga} 99118^{\circ}\right)$, dawnej Biblioteka Senatus Gedanensis, oraz Giacomo Franco, Habiti d'huomeni et donne Venetiane, Wenecja, ok. 1610 (Nf $68564^{\circ}$ ) z ekslibrisem Schwarzwaldów (podziękowanie za udostępnienie dla dr Marii Otto z Biblioteki PAN w Gdańsku) (Günther i Kleefeld 12-13),

${ }^{30}$ Giacomo Franco, Habiti delle donne venetiane, Wenecja ok. 1591-1609, il. o wym. $28 \times 21$ 
W Wenecji działał także ilustrator i wydawca Giacomo Franco. We wczesnych latach 90. XVI wieku przygotował Habiti delle donne venetiane („Stroje weneckich kobiet”) oraz Habiti d'huomeni et donne („Stroje mężczyzn i kobiet"), które wydano w 1609 i w 1610 r. Każda ze stron ukazywała wspaniale odziane kobiety. Inspiracją do wydania rycin kostiumów mógł być dla niego sukces traktatu z 1590 r. pt. Diversarum nationum habitus Pietro Bertellego (Art and Love 147-148, cat. 65). Plansza 11 przedstawiała sławną kurtyzanę, która naśladowała styl ubioru i prezentacji zamożnych kobiet, tzw. donne venetiane. W wydaniu rycin Franco z 1614 r. zebrano wyobrażenia weneckich piękności, stały się one pamiątką atrakcji miasta. Tego rodzaju wydawnictwa kupowali podróżujący do Wenecji kupcy, a także studenci $^{31}$. Trzy z plansz zaprojektowanych przez Giacomo Franco do Habiti delle donne venetiane były poświęcone młodym pannom. Kobiety przedstawiono pod kotarą zawiązaną $\mathrm{w}$ węzeł. Jedna $\mathrm{z}$ plansz pokazuje, jak panny były prezentowane podczas rytualnego pokazu zwanego parentado. Tak ukazał wenecką pannę młodą w czasie święta Wniebowstąpienia Jost Amman, gdy obchodzono symboliczne zaślubiny Doży z morzem (Art and Love 47 oraz cat. 65,148 , przyp. 9). Tradycja publicznej prezentacji młodej damy pod baldachimem w towarzystwie ojca lub opiekuna w obrazach przedstawiana jest pod węzłowym baldachimem (il. 5b) (Art and Love cat. 65). Ze względu na zainteresowanie humanistów kulturą antyczną ta wenecka, morska tradycja była łączona $\mathrm{z}$ mitologicznymi odniesieniami pięknych kobiet do bogini Wenus i bóstw morskich, nereid. Te ostatnie, znane z antycznych sarkofagów i literatury starożytnej, na nowo adoptowanej, wpłynęły na rodzaj prezentacji w zamawianych także u Möllera portretach.

W Gdańsku znany był portret stanowy, wzmocniony obserwacją portretu arystokratycznego. Mógł przedstawiać stojącą postać w całości lub w ujęciu do kolan. Taki wizerunek, modny pod koniec XVI wieku, uformowali portreciści wędrujący po Europie, m.in. Frans Pourbus Starszy, Adriaen Thomas Key, Frans Franken I, Michiel van Mierevelt i Antonius Moro. Portret podkreślał status społeczny i bywał zamawiany z okazji ważnych wydarzeń rodzinnych (Tylicki, „Obraz” 41-58; Jaśniewicz, „Małżeństwo” 25). Do szczegółów obrazu, podnoszących znaczenie portretowanej osoby, należała w przypadku Portretu patrycjuszki Möllera podwieszona tkanina, strój i biżuteria.

cm, The Metropolitan Museum of Art, mogły być katalogiem strojów albo zbiorem weneckich piękności. Pierwsza prośba o pozwolenie na druk plansz nosi datę 16 listopada $1591 \mathrm{r}$. (Art and Love, 47- 48, Fig. 37; 147, cat. 65).

${ }^{31}$ Można sądzić, że weneckie księgi ubiorów zainspirowały Möllera, by stworzyć księgę strojów gdańskich. 
Patrycjuszka nie powinna zostać przedstawiona $\mathrm{z}$ taką ilością biżuterii, regulowały to ordynacje w sprawie stroju mieszczańskiego (Bogucka 143; 161- 164; 203; 219; Kizik, „Ubiory” 19; 23-25). W grę wchodził jednak prestiż, a na kształt obrazu wpływ miał reprezentacyjny portret arystokratyczny o charakterze intelektualnym, odpowiadający włoskim portretom manierystycznym tzw. niejednoznacznym, wiązanym z literackimi metaforami. Takie portrety powstawały w latach 50 . i 60 . XVI wieku dla arystokratów we Florencji, np. Angolo di Cosimo Bronzino, Portret Ludovico Capponi (15501555, New York, kolekcja Frick) (il. 6 a) (Art and Love 45, il. 34). W tych włoskich uwagę widza skupiano na tajemniczości, powściągliwości i melancholii pokazywanych osób. Tak charakteryzowano kobiety w ówczesnym malarstwie Italii i w teoretycznych traktatach. Agnola Firenzuoli w wydanej we Florencji w 1548 r. księdze Della bellezza delle donne, sławiąc piękno kobiece, chwalił dystans i nieprzystępność. Baldassare Castiglione ukuł termin gravità, oznaczający powagę i surowość portretowanych twarzy, które miały wskazywać na siłę ducha i wszelkie zalety intelektualne. Te cechy były domeną reprezentacyjnego porteru dworskiego, tworzonego dla widzów o wysmakowanych gustach. Odpowiadały oczekiwaniom niemieckiego i niderlandzkiego patrycjatu pod koniec XVI wieku (Nevitt 80). Omawiany konterfekt z nutą poetyckiej atmosfery nostalgii i uczuciowości przypomina swą psychologiczną warstwą florencki i wenecki portret samotnych, myślących mężczyzn i wrażliwych kobiet z ok. 1. poł. XVI wieku, np. Paolo Caliari (Veronese), Portret kobiety znany jako Countess Nani or La Bella Nani (ok. 1560) czy Alessandro Allori (ok. 1545-1561), Portret Lukrecji de Medici (1560, The North Carolina Museum of Art) (il. 6b) ${ }^{32}$. Na twarzach kobiet maluje się to, co Baldassare Castiglione w Libro del Cortegiano nazwał dissimulazione, czyli pozorna łatwość osłaniająca trudność sztuki. Dzieła manieryzmu odznaczały się nonszalancją, kryjąc na pozór prostotę. Ta jednak zawierała sprezzatura, czyli wyrafinowanie. Wykwintność portretu była odzwierciedlona w pomyśle na dzieło. Pozornie banalne rekwizyty miały subtelny i niespodziewany przekaz. Często w malarstwie portretowano arystokratów jako idealnych modeli, w sensie opanowania i powinności moralnych względem teraźniejszych i przyszłych cnót, o których pisali moraliści (Bleyerfeld 223; Fudge 326).

Jednocześnie myśli związane $\mathrm{z}$ siłą miłości wyobrażoną na tych portretach mogły być dwuznaczne lub wskazywać na wierność. Zwracano uwagę na namiętność w miłości w połączeniu z normami moralnymi i prawnymi

\footnotetext{
${ }^{32}$ Portret został namalowany dla Francesca de Medici, brata Lukrecji, przed wyjazdem Lukrecji na dwór męża Alfonso II d'Este.
} 
(Jaśniewicz, „Małżeństwo” 3-16). Portrety młodych kobiet i mężczyzn zamawiano z potrzeby upamiętnienia stanu afektu, a w kręgach włoskich humanistów obstalowywano portret do specjalnej kolekcji konterfektów (Compagnia degli amici) (Nalezyty 86-87). Sporządzano także portrety pod wpływem nagłej śmierci bliskiego człowieka. Obdarowanie kogoś portretem było wtedy najwyższą formą uznania wartości drugiej osoby, przynależności do grupy przyjació $1^{33}$, afektu do męstwa, uczoności, pracy nad sobą, itp. W Gdańsku patrycjat cenił zapobiegliwość, upodobania intelektualne i zainteresowanie pięknem (Bogucka 245). Należy podkreślić artystyczne wyrafinowanie Portretu patrycjuszki gdańskiej. W tamtym czasie w Gdańsku właśnie Möller i jego warsztat wykonywali najbardziej prestiżowe zamówienia.

Anton Möller (ok. 1563-1611) pochodził z Królewca. W latach 15781585 uczył się u Antoniego Millerta z Nadrenii. Przed 1586 r. w dziełach Möllera brak jest wpływów włoskich, widoczne jest natomiast oddziaływanie malarstwa flamandzkiego i niemieckiego ${ }^{34}$. Oglądając prace Möllera malowane po 1590 r., można dostrzec inspirację manierystycznym stylem rysunków florenckich mistrzów, zwłaszcza Pontormo. Taki rodzaj rozmachu w kształtowaniu postaci musiał być nabyty z autopsji. W obecnych jednak badaniach neguje się podróż malarza do Włoch (por. Tylicki, Rysunek gdański 177). Przed 1939 r. dostrzeżono włoskie wpływy w malarstwie Möllera (Ehrenberg 181-190; Gyssling 4-6; 21-23; Drost 118; Labuda, „Anton”; Harasimowicz, „Doctrina” 93; „Der Danziger” 77-105), a Cluny [THIEME BECKER, G. Cuny, hasło Anton Möller]) i Gyssling postawili tezę o podróży Möllera do Italii ${ }^{35}$. Wiadomo, że Möller pracował dla uczonego weneckiego Marka Otobono (Pałubicki, Malarze t. 2 540). W bibliotece seminaryjnej w Pelplinie znaleziono wenecki druk poświęcony obyczajom pogrzebowym, w którym umieszczone są wpisy trzech kolejnych właścicieli dokumentu: Antona Möllera, Hermana Hana Młodszego i Johanna Kriega (na temat odkrycia: Tylicki, „Herman Han” 60).

${ }^{33}$ Na przykład Sebastiano del Piombo, Portret Vittorii Colonna?, ok. 1530, Museu Nacional d'Art de Catalunya, Barcelona (il. 6 c); Girolomo da Capri (?), Portret Kardynała Ippolito de Medici i Monsignore Mario Bracci, po 1532, Londyn, National Galery. W obu portretach występuje zawiązana w węzeł tkanina, w znaczeniu - przyjaźń wszystko trzyma razem.

${ }^{34} \mathrm{Na}$ przykład naśladowca Antona Möllera, Portret Damy z róża, 1587, Muzeum Narodowe w Warszawie (nr. inw. MP 5394).

${ }^{35}$ Gyssling zwraca uwagę na odnalezione w 1741 r. przez gdańskiego kolekcjonera Andreasa Schotta dokumenty, wskazujące, że Möller podróżował do Wenecji, a także na włoskie źródła pośrednie, które mogą potwierdzać jego pobyt w Italii w okolicach Sieny. Z powodu (jak sądzi Gyssling) zawartych w Italii przez Möllera Starszego kontaktów wyjechał do Italii jego syn Anton Möller Młodszy i w 1632 r. przebywał w Perugii, gdzie malował freski (Gyssling 4-6; 21-24). 


\section{ANALIZA IKONOGRAFICZNA PORTRETU PATRYCJUSZKI GDAŃSKIEJ}

Mając na uwadze dokonane obserwacje i historyczny kontekst powstania Portretu patrycjuszki gdańskiej (il. 1a), warto poddać analizie ikonografię tego konterfektu. Występuje w nim zestawienie kotary upiętej w dwa węzły nad niewiastą $\mathrm{z}$ trzymanym przez nią $\mathrm{w}$ ręku owocem. Jest on kształtem i kolorem upodobniony do pigwy, ale faktura skórki nie zdradza nasyconego koloru pomarańczy, a owoc ma szypułkę odłamaną z pozostawionym śladem, może to być zatem gorzka pomarańcza Citrus aurantium, z której uzyskiwano olejek eteryczny (Podbielkowski). Smak pomarańczy jest kwaśny i gorzki. Owoce gorzkiej pomarańczy są lekko spłaszczone i pokryte jasnopomarańczową chropowatą skórką. Owoc na gdańskim obrazie jest lekko spłaszczony i namalowany tak, by przypominał cytrus.

Kotarę przedstawiano w portrecie europejskim XVI wieku, powołując się na formułę ikonograficzną baldachimu królewskiego (Wilhelm; Klauser 11501153; Schramm 722-727), stosowanego w malarstwie religijnym, jako symbolu władzy oraz uhonorowania ludzkiej godności i mądrości (Eberlein; Krüger). Baldachim wyróżniał osobę i chronił ją. Gdy podwieszona zasłona zostaje zaopatrzona w węzeł, staje się tzw. Nodus Herculeus (herculanus) (König 35; Hersch 109; Kobielus 219-239), czyli węzłem miłości. Był on stosowany $\mathrm{w}$ antycznej tradycji weselnej: zawiązany na pasku tuniki panny młodej - chronił kobietę i miał być rozwiązany przez pana młodego (Handwörtrebuch des Deutsche Aberglaubens 19-20). Metaforycznie odnosił się do symboliki zawarcia małżeństwa i szczęśliwego rozwiązania wszystkich problemów (sugerował opiekę, ochronę, cnotę), tak jak je rozwiązywał mężny Herkules. Znaczenie węzła w baldachimowo podpiętej tkaninie odnosi się do świata najwyższych wartości: dobra, miłości i piękna (mundus amoris). Przeplecenie w tkaninie symbolizuje harmonijne powiązania między dualnymi siłami uniwersum (w najprostszym schemacie: dobro-zło, mężczyzna-kobieta, itp.), integrację. Sama tkanina w sztuce gra rolę medium iluzji i wzmocnienia metafory upamiętnienia $\mathrm{w}$ duchu retoryki $u t$ poesis pictura erit ${ }^{36}$. Dodatkowo, gdy przy „węźle Herkulesa” przedstawiano w sztuce „złote jabłko”, chciano zwrócić uwagę na wiedzę o aspektach Erosa (piękno/dobro/pokora). Od XV wieku złota kula" (złote jabłko z Sadu Parysa) oznaczało z jednaj strony świat Erosa i jego dualizm, niestałość szczęścia, przeciwności losu -

\footnotetext{
${ }^{36}$ W obrazie Narodziny Wenus Sandra Botticelli za Wenus jest rozpinana tkanina, znak wywyższenia bogini i jej zalet (Ikonologie des Zwischenraums XI).
} 
z drugiej strony symbolizowało obfitość, marzenie człowieka o byciu doskonałym w miłości, uzupełnianiu się i rozumieniu partnera ${ }^{37}$. Trzymać jak Parys złotą kulę w dłoni to rozumieć, że musi istnieć binarność: szczęście i cierpienie, że wszystko jest sztuką wyboru. Taki sens przekazuje drzeworyt Geoffroya Tory Znak ,Y” z atrybutami nagrody i kary z 1529 r. ${ }^{38}$

W chrześcijańskiej Europie węzeł miłości jako znak zawarcia małżeństwa był stosowany w rycerskiej kulturze miłości i przetrwał w pasie ślubnym, który na białą suknię przywdziewała w dniu ślubu młoda oblubienica (novia domus). Węzeł i wymiana pierścieni ślubnych były znakiem siły zawiązanego nowego przymierza i małżeństwa. Do innych symboli należała wymiana mirtowych wieńców, splecenie rąk (dextrarum iunctio) i spisanie kontraktu ślubnego w obecności świadków (Insadowski 114; Mikocki 28-33; 44-73). Pojęcie „węzeł Herkulesa” oznaczało moc i wierność przyrzeczeniu. Węzeł symbolizował idealne połączenie duchowe i cielesne miłości, trwałość związku. Był wykorzystywany jako motyw podczas ceremonii zaślubin oraz w ikonografii małżeńskiej. Na starożytnych płaskorzeźbionych sarkofagach ze scenami weselnymi i na stelach Nodus Herculeus występował dodany do gestu concordia, zgody na małżeństwo, oraz tabulae nupitiales (rulonu kontraktu ślubnego). Oblubienica lewą ręką podtrzymywała zarzucony na głowę płaszcz lub fałdy sukni. Węzeł Herkulesa i podtrzymywany welon były wyrazem tej samej idei: głębokiej, nierozerwalnej miłości, nawet w obliczu śmierci (Grzybkowska, 190). W starożytności uniesienie draperii nad pokazywaną osobą oznaczało: bohater i zwycięzca, szczęście. Ten typ rozumienia baldachimowego tworu nad portretowaną osobą wszedł do nowożytnej ikonografii jako życzenie bogactwa, obfitości i szczęścia.

Rozpięta draperia z węzłem nad kochankami występowała na antycznych sarkofagach ukazujących trytony (Białostocki 83-97), nereidy i amory. Jednym z najstarszych tego typu jest sarkofag antyczny z Palazzo Mattei w Rzy-

\footnotetext{
${ }^{37}$ Eros - dążenie do dobra (mowa Arystofanesa w Platon, Uczta $i$ w komentarzach do niej M. Ficino z roku 1468/69: Commentarium in convivium Platonis, de amore) rozumiano jako poszukiwanie utraconej przez człowieka jedności z przeznaczoną dla niego połową, czyli poszukiwaniem samego siebie, a tym samym doskonałości (Orchard 59-62; Nalezyty 43). Por, portrety z Florencji, np. Angolo Bronzino, Portret damy w czerwonej sukni, 1532-33, Städelsches Kunstinstitut und Städtische Galerie, Frankfurt am Main. Na portrecie dama umieszczona pomiędzy dwoma pilastrami obejmuje złotą gałkę fotela, usytuowaną przy różańcu, który rozdwaja się w kształcie litery Y (Maniera 168-171).

${ }^{38}$ Przyjaźń/miłość rozumiano jako wymianę daru między osobami, wymianę zobowiązania moralnego (Grabińska 18-24). To kobieta wiąże mężczyznę swymi więzami. Taki sens był przekazywany w ikonografii: Sąd Parysa w powiązaniu z motywem Wyboru Herkulesa na rozstajnych drogach (Hercules Prodicos) (Friedrich 361-393 383-388).
} 
mie, znany z przerysu (Kalinowski 508, il. 75, por. przyp. 106, 526-527; 577). Innym przykładem jest rzymski sarkofag z rysunku Bernardina Ciferri (Biblioteka Eton College, Topham Collection, sygn. B.m. 4.1.) (il. 8a) (Foto Courtauld Institute od Art, London, według Mossakowski 165-214, il. 108 płaskorzeźba sarkofagu według rysunku Bernardina Ciferri), powtórzony we freskach Rafaela i jego kręgu w willi Farnesina w Rzymie w scenie Triumf Galatei (1511-1512) oraz spopularyzowany jako motyw tkaniny z węzłem w grafice (Białostocki 87, il. 3), widzianej również przez pryzmat seksualny w alegoriach aktu miłosnego jako favola de gli Androgeni (Orchard, Androgynität 100-101; Annäherungen 61; 92-96; Talvacchia 22-24, fig. 2-3, np. ryciny Marcantonia Raimondiego). Przeplecione nogi pary w miłosnym uścisku nieopodal węzłowej kotary oznaczały duchową jedność związku. Na tę interpretację miały wpływ wiersze weselne Owidiusza i Ktulusa. Temat był nobilitowany w XV wieku, oznaczał wszechwładzę miłości, Wenus. Niejednokrotnie $\mathrm{w}$ scenach wzorowanych na antycznych sarkofagach przedstawiano kobietę i mężczyznę w roli bóstw morskich, Neptuna i Venus Marina. Metaforę zaczerpniętą $\mathrm{z}$ antyku połączono z koncepcją ludzkiej godności i miłości. $Z$ tego modnego dialogu all antica $\mathrm{z}$ chrześcijańskim aspektem małżeństwa i miłości wywodzono symbolikę przyszłych obfitości, oznaczaną owocami. Przedstawiana $\mathrm{z}$ rozpiętą draperią nereida była interpretowana jako Venus Anadyomene i ukazywana między dwoma Erosami na podobieństwo Afrodyty (Heckscher, „The Anadyomene” (1956); „The Anadyomene" (1985) 127-164; Białostocki 94, 95, il. 12). Dlatego też na początku XVI wieku we włoskich sonetach i dialogach miłość, jej owoce porównywano do warzywnych i owocowych ogrodów, w których króluje Wenus (Art and Love 49-50).

W dekoracji willi Farnese, zbudowanej dla Agostino Chigi, w Loggii Amora i Psyche wykorzystano ten literacki wątek w połączeniu $\mathrm{z}$ opowieścią o Amorze i Psyche. W dekoracyjnie potraktowanych sklepieniach miłość upodobniona jest do owocowego ogrodu z wyobrażeniem Merkurego wśród owoców oraz Amora i Psyche, którzy wyrażają duchowy i cielesny kontekst miłości harmonijnej. Wszak Erosa, w myśl idei platońskich, jeszcze w XV wieku wyobrażały splecione ręce trzech rodzajów Wenus (np. Sandro Botticelli, Narodziny Wiosny, Uffizi, Florencja). Trzy kobiety obrazują trzy rodzaje miłości, które charakteryzują duszę ludzką. Jeśli się razem zwiążą, spowodują odwrócenie duszy od przyziemnej, zwykłej miłości, ku sprawom natury wyższej i ku Bogu. W ten sposób obrazowano ideę piękna w człowieku, wskazując na miłość zdolną do wyrzeczeń, wielkich czynów i prze- 
kształcenia charakteru, uczynienia jej lepszą w powściągliwości i równowadze, którą w obrazie Botticellego oznaczał Merkury.

Mit Wenus sławionej w poezji miłosnej z okazji małżeństw odżył już w XV wieku w Italii. Był wykorzystywany do dekoracji przedmiotów zamawianych $\mathrm{w}$ związku $\mathrm{z}$ ceremonią zaślubin $\mathrm{w}$ malarstwie, grafice, zdobnictwie spalliere (Barriault; Nützmann, Alltag 33), w skrzyniach (cassone) (Miziołek 48-80; 4856; il. 20,70) oraz w ikonografii spozalizio, czyli zaręczyn dziewicy (Randolph 121; Musacchio, Art, Marriage 136-159). Wśród motywów występowały postacie kochanków, ukwiecona łąka, wymiana pierścieni ślubnych, wieńców, darów i pasów ślubnych. Z okazji ślubu w Italii zamawiano zwykle dwie skrzynie. $\mathrm{W}$ środku jednej na wewnętrznym wieku przedstawiano mężczyznę, a na drugiej półnagą kobietę, leżącą na łące. Na jednym z takich przykładów pokazano nagą kobietę trzymającą pas z kwiatów, w czym pomaga jej putto. Tak zobrazowana Wenus z Amorem (il. 8c) występowała z motywem węzła miłości i tzw. złotym jabłkiem w towarzystwie Marsa, Merkurego, Herkulesa lub Parysa, $\mathrm{z}$ odniesieniem do umiaru. Te idee zostały odzwierciedlone także w malarstwie dekorującym desco da parto ${ }^{39}$. Następnie rozpowszechniły się na północy Europy. Dlatego tak interesującym w Möllera Portrecie patrycjuszki z kolekcji prywatnej w Kolonii z ok. 1590 r. (il. 7a) jest połączenie dwu motywów węzłowych Nodus Herculeus - w kotarze i w pasku narzeczonej, a znajomość ikonografii włoskiej ukryta jest w złotym pasie portretowanej, na którym występuje motyw putt ${ }^{40}$. Ręce modelki naśladują ułożenie rąk z Rafaela Portretu Magddaleny Doni.

W portretach kobiet XVI-XVII wieku pas w kształcie ogniw łańcucha, dodatkowo jeszcze zawiązany, symbolizował węzeł małżeński. Modny był w portretach narzeczeńskich i małżeńskich, często zakończony pommanderem (A Feast for the Senses cat. 16). Genezy łańcucha o splocie pancerzowym, przepasującego kibić kobiety, która ujmuje go dłonią i eksponuje, upatrywano $\mathrm{w}$ przedstawieniach związanych z kulturą dworu $\mathrm{w}$ Burgundii XV wieku (Kühne Abb. 24). Także w łańcuchach złożonych z wielu ogniw, zwanych „więź miłości”, jak ten na Portrecie Marsilio Cassotti i jego żony, Faustiny Assoniki Lorenzo Lotto (1523 r., Museo del Prado, Madrid).

Zarówno kotara węzłowa i złote łańcuchy, dzisiaj wyglądające na banalną dekorację, w portrecie XVI stały się formułą ikonograficzną (il. 1a; 6c),

${ }^{39}$ Były to tace dawane położnicy z okazji urodzenia dziecka (Musacchio, The Art and Ritual, il. 47 na 65 ; il. 61 i 62 na 79 ).

${ }^{40}$ Wnętrze skrzyni przedstawiające Wenus i Amora trzymających pasek panny młodej, Florencja 1440-1445, Museo Privato Bellini, Florencja (Art and Love 134-135, cat. 58a I 58b). 
służącą za znak najwyższych wartości duchowych, czyli sancta Venere (Giovannni di Francesco Nesi nazywał ja sacrata e vera dea - za: Heckscher, „The Anadyomene” 3-7). Były metaforą Erosa, nadającą się do wyrażenia erotycznego kontekstu miłości i jej walorów duchowych (równowagi i mądrości w każdym związku, idea zgody). Tak zwana formuła węzła w kotarze oznaczała więź, czyli dążenie do dobra przez mądrość. Sądzono wówczas, że wartościowa postawa człowieka polega na odkryciu jedności we własnej duszy, zobaczenia siebie w innym i w harmonii z Bogiem. Mężczyzna i kobieta są jak dwie połówki jabłka. Istotą świata jest dualizm. Concordia jest siłą budującą zgodne małżeństwo, a w sensie wyższym równowagę odzwierciedlającą się w duszy i w ciele, wiodącą do felicitas i pax ${ }^{41}$. Gdy połączą się przeciwieństwa, tworzy się harmonia, zestrój. Przezwycięża on niezgodę i wiedzie do piękna. Symbolem łączenia przeciwieństw w XV-XVI wieku w kontekście niebiańskiej miłości były wizerunki Amora i Psyche oraz Marsa i Wenus w towarzystwie Merkurego (na tle drzewa pomarańczy, przepleceni wstęgą, np. Andrea Mantegna, Parnas, Paryż, Luwr) (Ferino-Pagden 200). Na temat genezy tego motywu pisał Kurt Flasch (91). Węzły miłości oznaczały aspekt duchowy i cielesny miłości, wytrzymałość i trwałość, jej bezinteresowność, także w przyjaźni, w wierze, co wykorzystano w emblematyce religijnej ${ }^{42}$, hieroglifice, heraldyce i alegoriach (Turner 246-247). Teorią węzłów miłości zajmowali się humaniści XV wieku: Marsilio Ficino, Leone Battista Alberti i Leonardo da Vinci. Dla Albertiego węzły miłości oznaczały stronę duchową miłości, która poprzez przyjaźń odzwierciedla w twarzy przyjaciela nasze ,ja”. Przyjaźń opisał Alberti w Della Famiglia, a także w De amicitia i Alulli (Auerenhammer 158-161). W medalach i portretach XV i XVI wieku można obserwować motywy węzłowe rozumiane wymiennie jako metafory miłości lub przyjaźni (nodus amicitiae) (Witte 7376), jako emocjonalne połączenie dwu dusz. Dla Ficina oznaczały one wieczne węzły miłości, które oplatają świat wiążąc ludzi, zdarzenia, los, duszę świata i Stwórcę ${ }^{43}$.

Pietro Bembo nadał swojemu poematowi tytuł Gli Asolani (1505 r.) (Clough 16-45; Nalezyty 6, 23, 33, 44). Próbował w nim odpowiedzieć

${ }^{41}$ Humaniści włoscy strukturę splecenia rozumieli jako wyobrażenie centrum unaoczniające porządek, mądrość Stwórcy i wielkość stworzenia. Przeciwstawne siły zostaną zrównoważone przez splecenie ich w węzeł, co symbolizowało umiar, szukanie równowagi i zgodności.

${ }^{42}$ Crispin de Passe Starszy, miedzioryt według Maertena de Vos, Złoty łańcuch Platona, wzajemnej harmonii i jedności w dziewięciu grupach ukazujący działanie i zależności uniwersum, Rijksmuseum Amsterdam (Kaulbach i Schleier 75, il. 17.1).

${ }^{43} \mathrm{Na}$ jednym $\mathrm{z}$ medali padewskich Pasieri przestawił Androgyne z napisem PHILOSOPHIA COMITE REGREDIMUR ( $Z$ filozofią jako towarzyszem wrócimy [do niebiańskiej ojczyzny]). 
na pytanie, dlaczego mężczyzna i kobieta poszukują się. Cierpkość i słodycz (amaro i amore) łączą się w miłości. Sądził, że poszukiwanie inności jest dążeniem do jedności utraconej po grzechu pierworodnym. Miłość traktował jako boski dar pojednania człowieka z drugim człowiekiem (Kidwelly 100113). Dobra miłość bowiem jest wieczna, lojalna i platoniczna. Co ciekawe, w tym właśnie środowisku zamawiano pierwsze portrety z kotarą związaną w węzeł, do których pozowały kobiety intelektualistki. Jedną z nich była Vittoria Collona. Jej konterfekt przeznaczony do kolekcji portretów przyjaciół Pietra Bemba namalował Sebastiano del Piombo (il. 6c). W zamierzeniu odnosił się do przyjaźni i idei platonicznej miłości (Nalezyty 87-91; Grabski; Clough 9-33). Do podobnych portretów intelektualistów z węzłową kotarą należy zaliczyć Portret starego mężczyzny $w$ kotnierzu futrzanym Prospero Fontany (1512-1597). Obok portretu uczonego na tle węzłowej kotary przedstawiano sentymentalnych i uczuciowych młodzieńców ${ }^{44}$. Portret z kotarą węzłową został przyswojony przez artystów północnoeuropejskich wraz z wpływami malarzy włoskich działających na francuskim dworze Franciszka I, a stał się modny, gdy Maria Medycejska poślubiła Henryka IV. Warto wymienić tu dwa obrazy: François Clouet (1510-1572), Dama w kapieli (National Gallery Washington), uważany za alegorię ludzkiego szczęścia, oraz Portret Marii de' Medici autorstwa Fransa Pourbusa II (Uffizi) ${ }^{45}$. Dużą rolę w transmisji motywów włoskich odegrały także podróże malarzy i zleceniodawców portretów. Niewątpliwie ten czynnik wpłynął na wybranie sposobu ukazania modela w Portrecie patrycjuszki z MNG. Anton Möller w obrazie podkreślił moment prezentowania przez niewiastę, pod zawiązaną w węzeł kotarą, owocu. Eksponowanie jabłka, cytryny, pomarańczy, pigwy jako atrybutu w obrazie było modne w XVI-wiecznym malarstwie Italii przedstawiającym Maryję z Dzieciątkiem w znaczeniu miłości Bożej ${ }^{46}$. Tu jabłka chętnie zastępowano pomarańczami. Tak samo jak w portretach o poetyckim wyrazie melancholii z kręgu Giorgione, np. Portret podwójny młodzieńców ze zbiorów kardynała Ludovico Ludovisiego (1512-13, Palazzo Venezia) (il. 9a).

Pomarańcze swoją złocistą barwą przypominały blask złota. Bogactwo utożsamiane było ze złocistymi cytrusami z ogrodów Hesperyd, poświę-

${ }^{44}$ Girolomo da Capri (?), Portret Kardynata Ippolito de' Medici i Monsignor Mario Bracci, po 1532 , Londyn, National Galery.

${ }^{45}$ Por. kopię wykonaną przez Giovana Lionardo Henera według Fransa Pourbusa II Caterina e Maria de'Medici donne al Potere. Firenze Celebra il mito di due regino di Francia, oprac. C. Innocenti, „[exhibition cat.]”, Florencja Palazzo Strozzi, 24.10. 2008 - 8.02. 2009, Firenze 2008, 68, kat. 11 .

${ }^{46}$ Giovanni Agostino da Lodi, Madonna z Dzieciatkiem i aniołem, 1510, Brera, Mediolan. 
conych Wenus. Ich słodko-gorzki smak odnosił się do cierpkiego smaku każdej ziemskiej miłości. Właśnie to znaczenie tzw. złotych owoców Wenus na drzewie cytrusowym (malus medica) podkreśla dwuznaczność owoców cytrusowych - leczą i zadają ból. W sztuce włoskiej XVI wieku gorzkie pomarańcze były wykorzystywane w portretach zakochanych mężczyzn. Służyły za znaki dźwiganego przez nich brzemienia miłości, wskazując na jej ambiwalentną jakość, oscylującą między radością a bólem, zawiścią a zauroczeniem, radością a smutkiem. Jednocześnie gorzkie pomarańcze wskazywały na zmysłowe pragnienia kochanków, jak na Desco da Parto (il. 9b) czy w rycinach Dzieci planety Wenus, na których pokazywano pary tańczące wokoło pomarańczowego drzewka w ogrodach miłości na niderlandzkich grafikach XV wieku ${ }^{48}$. Ciekawe są obrazy, na których do drzewa pomarańczy przywiązany jest zakochany mężczyzna, np. Dosso Dosi, tzw. Św. Sebastian (ok. 1524-26, Brera, Mediolan) (Koos, 53-54). Mundus amoris obejmowało znaczenia świeckie i religijne: ziemską miłość i miłość do Boga, umożliwiającą człowiekowi zbawienie. Wydaje się, że młoda gdańszczanka przedstawiona na tle kotary $\mathrm{z}$ dwoma węzłami personifikuje concordia, siłę spajająca miłość małżeńską. Moc jej to tzw. złote jabłko opisane w Emblemata Alciatiego jako owoc cytrusowy o dwuznacznym znaczeniu (il. 9c) (Koos 53-54). Nie dziwią więc podejmowane przez badaczy interpretacje owocu w obrazie. Jaką zatem metaforę kryje w sobie w XVI wieku gorzka pomarańcza? Na odpowiedź naprowadza nas naga Wenus, eksponująca pomarańczę w towarzystwie Amora z łukiem i strzałą, przedstawiona na jednej ze ścian w willi Farnesina ${ }^{49}$. Podobny rodzaj wizerunków Wenus powstaje na północy Europy w latach 90. XVI wieku. Zaproponował je Hendrik Goltzius. Przedstawiały nagie lub zaledwie okryte tkaniną Wenus z jabłkiem (Wenus trzymajaca jabtko, ok. 1598, rysunek, 16×7,5 cm, Haarlem, Teylers Museum). Nawiązywały do wyobrażeń Ewy ze scen grzechu pierworodnego (Jan Saenredam według Hendrick Goltzius, Grzech pierworodny, 1597). Jej wizerunki wykorzystywano w takim ujęciu w alegoriach pięciu zmysłów,

${ }^{47}$ A Feast for the Senses 256-257 (Triumf Venus, taca urodzinowa, Mistrz Charles of Durazzo (Francesco di Michele?), ok. 1400 (Luwr, Paryż), nr. inw. Diameter, 51 cm, R.F.2089, z sześcioma legendarnymi kochankami: Achillesem, Tristanem, Lancelotem, Samsonem, Parysem i Troilus, którzy są rażeni mocą Wenus promieniującej z drzewa pomarańczy).

${ }^{48}$ Pary znajdują się wokół drzewa pomarańczy. Mistrz E.S., Ogród miłości, ok. 1460, miedzioryt, Bibliothèque Nationale de France, Paris (Ea 40 ré) (A Feast for the Senses kat. 118, 148 249 , il. na 249).

${ }^{49}$ Baltassare Peruzzi, Wenus z Amorem, 1518, Villa Chigi (Farnesina), Rzym (Turner 127, il. 2. 37). 
np. Jacob Matham, Wenus z Kupidynem i Satyrem - alegoria zmysłu wzroku (ok. 1600, miedzioryt) czy Jan Saenredam według Goltziusa, Wenus i Kupi$d y n$ (ok. 1595) (Sluiter 114-125), także odnosząc je do mitologicznych bohaterek, np. Hendrick Goltzius, Helena $(1615$, obraz, olej na płótnie, $115 \times 83 \mathrm{~cm}$, Montreal, Collection David G. Carter), odkrywając w nich zauroczenie kobietą i jej niebezpieczny powab wiodący do ognistej miłości, ale i przyczynę kłopotów. Na rycinach Jana Saenredama według Golziusa, np. Wenus i Kupidyn (ok. 1595), czy Jacoba Mathama, pod tym samym tytułem z 1612 r., jest podkreślone zainteresowanie jabłkiem Wenus otrzymanym od Parysa. Wenus jest uosobieniem piękna i jednocześnie niebezpiecznej uwodzicielki, jak na grafice Goltziusa Wenus $i$ Amor z 1595 r. czy Wenus $i$ jej dzieci, ok. 1596 (il. 2b) (Sluiter 127, 130). Wenus postrzegano bardziej w sposób poetycki jako harmonijną, ożywczą, acz zmysłową miłość rządzącą bogami i śmiertelnikami, którzy są nieustannie dręczeni jej siłą. Napis pod dziećmi bogini Wenus ze wzniesionym w górę płonącym sercem głosił, że ci, którzy służą jej w nieczystości, zostaną pozbawieni bogactwa i poczucia humoru. Dzieci Wenus lub ci, którzy się z jej znakiem, cytrusem Wenus, utożsamiają, widzą w nim płomień serca. Gorzka pomarańcza Wenus, czyli ogień zapalny serca, był opisywany w poezji miłosnej, emblematyce i epitalamiach i rozmaicie nazywany: Venus-brandt - ogień Wenus, Venus pranks - dowcip Wenus, Venus tochten - Wenus namiętności, Venus spel - gra Wenus, Venus werck - praca Wenus, Venus dienaren - służba Wenus, Venus wichten dziewczyny Wenus, Venus goet - wędzidło Wenus, Venus dierkens - zwierzęta Venus, Venus scholierkens - uczeń Wenus. Wyrażał wiele różnych odcieni żarliwości miłości. W tzw. jabłku Wenus mieściła się zatem potencja „siły miłości”, która dręczy młodzieńczych i starych jej zwolenników. Miłość każdemu obiecuje owoc - to, czego mu brak, o czym marzy, młodzieńczym kochankom gwarantuje siłę reprodukcji. Była to prezentacja piękna i powabu, ale i konsekwencji. Wskazywano na grację jako czynnik zmysłowy, ale tym samym uczulano, że tuż obok stoi superbia $i$ vanitas. Taki wizerunek miłości uwodził przez zmysł wzroku, działał też na inne zmysły, np. zapach pomarańczy z którego sporządzano olejki, ale uświadamiał, że wszytko może się zdarzyć, łącznie z zagrożeniami i śmiercią obiektu miłości. Goltzius do jednej z rycin dał opis: Venus en haer nichte (Wenus i jej kuzynka), czyli Śmierć (Sluiter 131). Wenus w roli personifikacji zmysłu wzroku oznaczała miłość do przedmiotu uwodzenia. Stąd także gdańska patrycjuszka trzymająca cytrus, znak swej siły uwodzenia, występuje w roli personifikacji miłości wiążącej swego zwolennika. 
W Portrecie patrycjuszki gdańskiej zostaje podkreślona rola miłości i piękna w życiu człowieka. Ten temat charakteryzował XV-wieczną kulturę zaślubin w połączeniu z poezją miłosną i odnośnikami do Biblii. W Triumfach Petrarki (1354-74) miłość stawała się więzieniem czystości ${ }^{50}$. W Hypnerotomachii Poliphili Francesco Colonny ${ }^{51}$ miłość stanowiła preludium do małżeństwa, była pochwałą małżeństwa, i to nie wstrzemięźliwego. Nagroda w miłości miała być jednak odłożona do czasu ślubu. W I księdze Poliphilio przebija za pomocą złotej strzały Kupidyna zasłony z napisem YMHN (Hymen, bóg zaślubin). Zasłony odsłaniają Wenus, która daje parze pierścienie i przyjmuje ich przyrzeczenie. W drugiej księdze inna ceremonia odbywa się w obecności kapłanki Wenus (św. Matki), która potwierdza śluby pieczętowane pocałunkiem. Ów temat zasłony, baldachimu, skrywa to, co najcenniejsze - czystość intencji duchowych. Podkreślały to już baldachimy nad Madonna z Dzieciatkiem (Eberlein 83-87). W XV wieku ukazywano oblubienicę na kwietnej łące nieopodal wnętrza domu, z łożem ozdobionym tkaniną zawiązaną w węzeł, jak na ilustracji do Hypnerotomachi Poliphili (i1. 8c), tak symbolizowano tęsknotę serc jako preludium do małżeństwa (Art and Love 141-142).

Występująca w portrecie gdańskim węzłowa zasłona jest wyznacznikiem prywatnego charakteru konterfektu niewiasty zamężnej. Tak zwany Ehrenportrait - portret „ku czci”, uczyniony dla osoby kochanej lub by pamiętać miłość łączącą dwoje ludzi. Kobieta sprawia wrażenie wyalienowanej, a prezentuje gorzką pomarańczę. Pomarańcze i brzoskwinie wskazywały na płodność i bogactwo daru miłości, jakim są dzieci. Była to owa siła węzłów miłości, którą już w XV wieku pokazywały ryciny, np. Baccio Baldini, Młodzieniec przywiazany do drzewa pomarańczowego, Londyn, British Museum (il. 9d), któremu kobieta kradnie serce (Renaissance Love. Eros 58, il. 12), czy rycina Cristofano Robetta, Mężczyzna przywiązywany do drzewa miłości (1525), czyli pomarańczy. Geneza tego typu scen sięga fresku w Palazzo Schifanoia, gdzie Wenus z Marsem reprezentują alegorię miesiąca maja. Łańcuch wiąże kochanków, ale to Wenus trzymająca złote jabłko jest dominująca. Przed nią klęczy Mars. Miłość wiedzie do owocu małżeństwa dziecka, nad którym wisi na łańcuchu miłosnych splotów gorzka pomarańcza, jak w obrazie Baltasare Estense, Portret Rodziny (Baierische Staatsgemäldesammlung Monachium) (il.10a) (Żygulski, „Ze studiów” 23, il. 22).

\footnotetext{
${ }^{50} \mathrm{~W}$ XV w. częstym tematem przedstawień na meblach małżeńskich była bitwa między czystością a miłością. Art and Love 142

${ }^{51}$ Wyd. Aldus Manuntius, Wenecja 1499: Art and Love 142-143; Klimkiewicz.
} 
Tak pojmowany motyw złocistej pomarańczy gra rolę serca i przywiązania. Motyw łańcucha zamkniętego kłódką z kluczem chętnie wykorzystano w $\mathrm{Al}$ bum Amicorum (il. 10b) lub w alegoriach oblubieńca i oblubienicy spętanych łańcuchem i trzymających serce ${ }^{52}$. Wymowy dopełniały, jak dawniej w poezji humanistów włoskich, aluzje mówiące o sile kobiet w uwodzeniu mężczyzn, która tkwiła w pięknie oczu ukochanej ${ }^{53}$. Na tym właśnie polega filozoficzna siła Portretu patrycjuszki gdańskiej, stworzenia „więzienia miłości”. Taki stan oblubienicy lub oblubieńca opisywał w Canzoniere Petrarca. Jej pomarańcza jest tym samym, czym złota kula w alegoriach miłości w sztuce XV-XVI wieku - jest gorzką pomarańczą, np. Agnolo Bronzino, Alegoria Wenus z kupidynem (1540-1545, National Gallery, Londyn) (il. 10c); Alessandro Allori, Wenus i Kupidyn (Uffizi, Florencja) lub Annibale Carracci, Wenus i Kupidyn (1592, Galleria Estense di Modena) ${ }^{54}$. W tych obrazach miłość wydaje się być pięknym marzeniem, gdyż Wenus trzyma gorzką pomarańczę lub zrywa ją na znak cierpienia w miłości jak na obrazie Parisa Bordone, Alegoria - Mars Wenus, Wiktoria i Kupido (ok. 1560, KHM Wiedeń) (Transalpinum, 176-177). W Portrecie patrycjuszki z Gdańska pieczętuje je czepiec z pereł. Wszak perły symbolizowały harmonię miłości i małżeństwa wraz z cierpieniem, które niesie życie (Jongh 69-97). Wszystko, co piękne w miłości, przypomina owoce cytrusowe jako tzw. malus medica, opisane w Emblemata Alciatiego (il. 9c) w odniesieniu do jabłka grzechu ${ }^{55}$. To oznacza w miłości wszystko - od afektów po cierpienie, stąd mundus amoris - „wszystko w miłości”.

W mieszczańskim konterfekcie z Gdańska mamy do czynienia nie tylko $\mathrm{z}$ dostojeństwem modela, ale też $\mathrm{z}$ subtelnością znaczenia portretu ukrytą w jego obojętności. Tak potrafili obrazować nastrój w obrazie wielcy manieryści włoscy. Można by sądzić, że prezentacja owocu odbywa się z okazji oczekiwania na narodziny dziecka, jak chce Jaśniewicz (Jaśniewicz, Portret 395). Indyferentne jednak i przyćmione oblicze niewiasty emanuje na cały portret, a ciekawy szczegół widoczny po prawej stronie pod węzłem kotary

\footnotetext{
${ }^{52}$ Por. Palazzo Schifanoia, Mars i Wenus ze złotą kulą połączeni łańcuchem.

${ }^{53}$ Por. Baldassare Peruzzi, Wenus, 1518, fresk, Sala delle Prospetive, Willa Chigi, Farnesina, Rzym (Turner, il. 2.37, 127).

${ }^{54}$ Dzieła należą do kategorii concettisimo, w których na podstawie mitologii użyte personifikacje i ich atrybuty złożono w rebus. Odwołano się do liryki miłosnej Owidiusza (Ars amatoria i Amores) (Turner 319-327).

${ }^{55}$ Malum oznaczało i grzech, i życie, płodność i miłość. W Psalmie 2,3 jest mowa o niewygodnych dla człowieka pętach narzuconych przez Boga, dotyczących nieuniknionego losu. Konsekwencją grzechu jest utrata więzi z Bogiem. Symbolicznie przywrócić więź to pokonać alienację i osiągnąć doskonałość przez miłość.
} 
każe wątpić w całkowicie radosne przesłanie obrazu. Umieszczona tam taśma z małą kokardą, wiążącą fałdę tkaniny, to trzeci węzeł w obrazie, który może wskazywać na więź ze zmarłym dzieckiem (il. 2a). Podobne rozwiązania stosowano w malarstwie Italii jako rodzaj znaku pamięci, pozostający przy kochanych osobach (Koss 228-231). Patrycjuszka nie jest przedstawiona w sposób jednoznaczny, lecz z pogłębionym efektem - sprezzatura, określającym jej subiektywne i emocjonalne liryczne doznania. Czy te wskazówki wystarczą, by określić, kim jest kobieta przedstawiona w obrazie?

Przy braku źródeł archiwalnych, traktując obraz jako dokument czasów, w których powstał, należy sięgnąć po aparat heraldyczny i przypomnieć, że Möller w swoich portretach stosował barwy tarczy herbowej. Kolorystyka zastosowana w Portrecie patrycjuszki gdańskiej odnosi się do herbu rodziny Speymannów (il. 1a), co wskazuje, że mogła tu zostać przedstawiona Maria Judita Bahr (ok. 1574-1531. 1. 1625), żona Johanna Speymanna, z którą zawarł związek małżeński w kościele Najświętszej Maryi Panny w Gdańsku 29 lipca 1596 r. Portret zamówiony dla niej przez męża u Möllera mógł upamiętniać miłość małżonków i utratę zmarłego w 1599 r. syna Johana (ur. 30 lipca 1598 r., zm. 31 października 1599 r.) (Patrizier, Bürger Bd.1, 422). To wyznaczałoby czas powstania portretu na ok. 1599-1600 r. Był to okres wzmożonej aktywności Möllera w zleceniach dla Speymanna.

Analiza Portretu patrycjuszki gdańskiej uświadamia, że ta praca w swojej stylistyce wykazuje wpływ malarstwa niderlandzko-niemieckiego, a w ikonografii rozwija model obrazowy zaczerpnięty z tradycji malarstwa i grafiki włoskiej (Florencja, Wenecja). Portret patrycjuszki gdańskiej jest przykładem dbałości o splendor rodziny, dlatego wykorzystano wzór arystokratycznego portretu kobiecego, ale z subtelnością podkreślono wymiar etyczny, koncentrując się na symbolice Erosa. Tak pogodzono chrześcijańską tradycję małżeństwa z zainteresowaniami antykiem gdańskich mieszczan erudytów.

\section{BIBLIOGRAFIA}

\section{LITERATURA PRZEDMIOTOWA}

Allgemeines Lexikon der bildenden Künstler von der Antike bis zur Gegenwart (THIEME BeCKeR), oprac. H. Vollmer, B.C. Kreplin, L. Scheewe, H. Wolff, O. Kellener, red. Hans Vollmer, t. 25, Verlag von E.A. Seemann, 1931.

Amor Polonus czyli milość Polaków. Katalog wystawy marzec-sierpień 2010, Muzeum Pałac w Wilanowie, red. Teresa Grzybkowska, Dominika Walawender-Musz i Zdzisław Żygulski jun., t. 1, Muzeum Pałac w Wilanowie, 2010. 
Aurea Porta Rzeczypospolitej. Sztuka Gdańska od polowy XV do końca XVIII wieku, t. 1. Katalog wystawy Muzeum Narodowe Gdańsk, maj-sierpień 1997, red. Teresa Grzybkowska, Muzeum Narodowe Gdańsk, 1997.

Chodyński, Antoni Romuald, „De gustibus est disputandum. O wartości złota w życiu Gdańszczan", Gust gdański. Materialy sympozjum 24 października 2004, red. Bronisława Dejna i Jakub Szczepański, Nadbałtyckie Centrum Kultury, 2004.

Drost, Willi, Danziger Malerei vom Mittelalter bis zum Ende des Barocks. Verlag für Kunstwissenschaft 1938.

Ehrenberg, Hermann, „Anton Möller, der Maler von Danzig. Ein Beitrag zur Kenntnis des Einflusses der italienischen und der niederländischen Kunst auf die deutsche Malerei der Spätrenaissance", Monatshefte für Kunstwissenschaft, t. 11, z. 7, 1918, ss. 181-190.

Gosieniecka, Anna. „Sztambuch Michała Heidenreicha”. Sarmatia artistica. Ksiega pamiatkowa ku czci profesora Władysława Tomkiewicza. Państwowe Wydawnictwo Naukowe, 1968, ss. $73-82$.

Gosieniecka, Anna. Malarstwo Gdańskie XVI i XVII wieku. Muzeum Pomorskie, 1957.

Groth, Andrzej. „Bahr Szymon”. Stownik biograficzny Pomorza Nadwiślańskiego, red. Stanisław Gierszewski, t. 1, Gdańskie Towarzystwo Naukowe, Uniwersytet Gdański, 1992, s. 54.

Grzybkowska, Teresa, „Mit i antykizacja w sztuce gdańskiej”. Mit Odysa w Gdańsku. Antykizacja w sztuce polskiej. Materiaty z Konferencji „Mit Odysa w Gdańsku” zorganizowanej w listopadzie 1998 roku w Nadbattyckim Centrum Kultury, red. Teresa Grzybkowska, Wydawnictwo Uniwersytetu Gdańskiego, 2000.

Grzybkowska, Teresa. Zloty wiek malarstwa gdańskiego na tle kultury artystycznej miasta 15201620. Wydawnictwo Naukowe PWN, 1990.

Günther, Otto, i Karl Kleefeld. Die Danziger Stadtbibliothek. Ihre Entwicklung und ihr Neubau. Druck von A.W. Kafemann, 1905

Gyssling Walter, „Anton Möller und seine Schule. Ein Beitrag zur Geschichte der niederdeutschen Renaissance Malerei”. Studien zur deutschen Kunstgeschichte, Heft 197, Hertz \& Mendel, 1917.

Harasimowicz, Jan. „Anton Möller - malarz, moralista, obywatel”. Biuletyn Historii Sztuki, nr 4, 1994, ss. 339-358.

Jaśniewicz, Aleksandra. „Małżeństwo w nowożytnym Gdańsku w świetle XVI- i XVII-wiecznych portretów mieszkańców miasta". Quart, nr 3 (25), 2012, ss. 3-16.

Jaśniewicz, Aleksandra. Portret w Gdańsku, od schyłku średniowiecza do późnego baroku (14201700). Malarstwo- rysunek. Muzeum Narodowe w Gdansku, 2018.

Kaleciński, Marcin. „Między strefą prywatną a publiczną. Ars „mitologica” i antykizacja we wnętrza domów i w ogrodach gdańszczan”. Gdańsk nowożytny a świat antyczny, red. Maria Otto i Jacek Pokrzywnicki, Wydawnictwo Bernardinum, 2017.

Kaleciński, Marcin. Mity Gdańska. Antyk w publicznej sztuce protestanckiej res publiki. słowo/obraz terytoria, 2011.

Kathke, Petra. Porträt und Accessorie. Eine Bildniform im 16. Jahrhundert. Reimer Verlag, 1997.

Kowalska, Helena, „Obraz Alegoria cnoty matżeńskiej. Klucz do drugiego oblicza sztuki Hermana Hana". Porta Aurea: Rocznik Zakładu Historii Sztuki Uniwersytetu Gdańskiego, t. 6, 1999, ss. 147-152.

Labuda, Teresa, „Gdańsk w malarstwie Antoniego Möllera”. Rocznik Gdański, t. 50, 1990, ss. 261-274. 
Labuda, Teresa, „Portret w twórczości Antona Möllera”. Studia z historii sztuki i kultury Gdańska $i$ Europy Pótnocnej. Prace poświęcone pamięci Doktor Katarzyny Cieślak, red. Jacek Friedrich i Edmund Kizik, Stowarzyszenie Historyków Sztuki, Oddział Gdański, 2003, ss. 115-134.

Labuda, Teresa. Antoni Möller malarz gdański przełomu XVI i XVII wieku, praca doktorska napisana w Instytucie Historii Sztuki UAM pod kierunkiem prof. dr. hab. E. Iwanoyki oraz prof. dr hab. K. Kalinowskiego, Uniwerystet im. Adama Mickiewicza, 1991 (maszynopis).

Leonardo da Vinci and the Splendor of Poland. A History of Collecting and Patronage. Museum of Fine Arts, Houston, Fine Arts Museum of San Francisco, red. Laurie Winters i Dorota Folga Januszewska, Milwaukee Art Museum, 2002.

Morka, Mieczysław. „Kilka uwag o wartość sygnatur oraz pisaniu ekspertyz”. Falsyfikaty dzieł sztuki w zbiorach polskich. Materiaty międzynarodowej konferencji naukowej 21-22 maja 1999, Instytut Archeologii UW, Oddziat Warszawski Stowarzyszenia Historyków Sztuki i Zamek Królewski w Warszawie, red. Jerzy Miziołek i Mieczysław Morka, Agencja Wydawniczo-Poligraficzna ARGRAF, ss. 250-269.

Mosingiewicz, Anna. „Antoni Möller (ok. 1563-1611) malarz”. Artyści w dawnym Toruniu, red. Józef Poklewski, TNT, 1985, ss. 44-52.

Nevitt, H. Rodney Jr. Art and the Culture of Love in the seventeenth-Century Holland. Cambridge University Press, 2003.

Nowacki, Dariusz. „Kilka zapomnianych gedanianów w zbiorach wawelskich”. Porta Aurea, Rocznik Zakładu Historii Sztuki Uniwersytetu Gdańskiego, t. 6, 1999, ss. 45-52.

Nowak, Zbigniew. „Schachmann”. Polski Stownik Biograficzny, red. Henryk Markiewicz, t. 35, Zakład Narodowy im. Ossolińskich - Wydawnictwo PAN, 1994.

Pałubicki, Janusz. Malarze Gdańscy. Malarze, szklarze, rysownicy i rytownicy w okresie nowożytnym $w$ gdańskich materiałach archiwalnych, t. 2, Muzeum Narodowe w Gdańsku, 2009, ss. 540-542.

Pszczółkowska, Lidia Z. „Speymann’. Słownik biograficzny Pomorza Nadwiślańskiego, red. Stanisław Gierszewski, T. t, red. Zbigniew Nowak, Gdańskie Towarzystwo Naukowe, Uniwersytet Gdański 1997, ss. 247-248.

Pszczółkowska, Lidia Z. „Speymen (Speiman, Speymann Jan”. Polski Stownik Biograficzny, red. Henryk Markiewicz, t. 41, Zakład Narodowy im. Ossolińskich - Wydawnictwo PAN, 2002, s. 80.

Rastawiecki, Edward. Słownik malarzów polskich tudzież obcych w Polsce osiadtych lub czasowo w niej przebywajacych, t. 2, Warszawa, Nakładem autora, 1851.

Rohde, Alfred. Königsberger Maler im Zeitalter des Simon Dach. Osteuropa-Verlag, 1938

Stownik biograficzny Pomorza Nadwiślańskiego, red. Stanisław Gierszewski, t. 1, Gdańskie Towarzystwo Naukowe, Uniwersytet Gdański, 1992.

Szmelter-Fausek, Bożena. „Badania obrazów Antona Möllera i Hermanna Hana jako przyczynek do rozpoznania gdańskiego warsztatu malarskiego ostatniej ćwierci XVI i pierwszej połowy XVII w.”. Materiaty konferencyjne IV Środkowoeuropejskiego Forum Doktorantów Historii Sztuki, Instytut Historii Sztuki UWr, 4-7 listopad 2009. Uniwersytet Wrocławski, 2010.

Szmelter-Fausek, Bożena. „Badania obrazów Antona Möllera i Hermanna Hana jako przyczynek do rozpoznania gdańskiego warsztatu malarskiego ostatniej ćwierci XVI i pierwszej połowy XVII w.", Historia Sztuki w dobie globalizacji. Materiaty IV Środkowoeuro- 
pejskiego Forum Doktorantów Historii Sztuki, Instytut Historii Sztuki, Wroctaw, 5-8 listopada 2009, Oficyna Wydawnicza Atut - Wrocławskie Wydawnictwo Oświatowe. Uniwersytet Wrocławski, 2013, ss. 21-29.

Tylicki, Jacek. „Han (Haan, Hahn, Hahn, Hane) Anton, Herman (Hermann)”. Algemeines Künstlerlexikon: die bildenden Künstler aller Zeiten und Völker, Bd. 69, VEB E.A. Seemann, Saur, De Gruyter, 2011, ss. 34-35.

Tylicki, Jacek. „Herman Han - dwa oblicza artysty”. Herman Han - mistrz światta i nokturnu. Narodziny baroku w malarstwie dawnej Rzeczpospolitej, red. Marcin Osowski, Wydawnictwo Bernardinum, 2008.

Tylicki, Jacek. „Herman Han, Holender z Gdańska”, Biuletyn Historii Sztuki, t. 71, nr 1-2, 2009, s. 201-204

Tylicki, Jacek. „Malarstwo i rysunek”. Prusy Królewskie - spoleczeństwo, kultura, gospodarka 1454-1772, red. Edmund Kizik, Muzeum Narodowe w Gdańsku, 2012.

Tylicki, Jacek. „Möller Anton d.J.”, Allgemeines Künstlerlexikon die bildenden Künstler aller Zeiten und Völker, Bd. 90, De Gruyter, 2016, s. 133-134.

Tylicki, Jacek. „Obraz Alegoria cnoty matżeńskiej. Klucz do drugiego oblicza sztuki Hermanna Hana". Biuletyn Historii Sztuki, t. 59, nr 1-2, 1997, ss. 41-58.

Tylicki, Jacek. Rysunek gdański ostatniej ćwierci XVI i pierwszej połowy XVII wieku, Torun 2005

\section{LiTERATURA PODMIOTOWA}

A Feast for the Senses: Art and Experience in Medieval Europe, red. Martina Bagnoli, Virginia Brilliant, Carla Casagrande, Emma Dillon, Barbara Newman i Christina Casagrande. Walters Art Museum, 2017.

Art and Love in Renaissance Italy. Katalog wystawy Metropolitan Museum of Art. New York 11. 11. 2008-16.02. 2009, red. Andrea Bayer, MetPublications, 2008.

Auerenhammer, Hans. „Liberalitas: The Image of a Friendly Virtute as a hidden self-Portrait in Leon Battista Alberti's Della pittura", Renaissance Love. Eros, Passion, and Friendship in Italian Art. around 1500, Italienische Forschungen des Kunsthistorischen Institutes in Florenz, I Mandorli, red. Jeanette Kohl, Marianne Koss i Adrian W.B. Randolph, Deutscher Kunstverlag, 2014, ss. 149-162.

Barriault, Anne B. Spalliera Paintings of Renaissance Tuscany. Penn State University Press, 2000.

Bauer, Matthias, Joachim Knape, Peter Koch i Susanne Winkler. „, Dimensionen der Ambiguität”. Zeitschrift für Literaturwissenschaft und Linguistik, z. 158, 2010, s. 7-75.

Bedaux, Jan Baptist. The reality of Symbols. Studies in the Iconology of Neterlandish Art 14001800, G. Schwartz/SDU, 1990.

Bertling, August. Danziger Frauentrachtenbuch aus dem Jahre 1601 getreuen Faksimile-Reproduktionen, neu herausgegeben nach den Original-Holzschnitten mit begleitendem Text, Danzig, Verlag von Richard Bertling, 1886, ss. 1-14.

Białostocki, Jan. „Nereidy w Kaplicy Zygmuntowskiej”. Treści dzieła sztuki. Materiały sesji Stowarzyszenia Historyków Sztuki. PWN, 1986, ss. 89-97.

Bleyerfeld, Yvonne. „Chaste, Obedient and Devout. Biblical Women as Patterns of Female Virtue in Netherlandish and German Graphic Art ca. 1500-1750". Simiolus, t. 28, nr 4, 2000/2001, ss. 219-250.

Bogucka Maria. Żyć w dawnym Gdańsku. Wiek XVI-XVII. Trio, 1997. 
Brandolph, Adrian W. Engaging Symbols. Gender, Politics and Public Art in fifteenth century Florence. Yale University Press, 2002.

Cieślak, Katarzyna. Kościół cmentarzem. Sztuka nagrobna w Gdańsku (XV-XVIII w.). Polska Akademia Nauk, Instytut Sztuki, 1992.

Clough, Cecil H. „Pietro Bembo's Gli Asolani of 1505”. Modern Languages Notes, t. 84, nr 1, 1969, ss. 16-45.

Daston, Lorraine, i Katherine Park. Wunder und die Ordnung der Natur 1150-1750. Eichborn, 2002.

Daston, Lorraine. „Die Lust an der Neugier in der frühneuzeitlichen Wissenschaft”. Couriositas. Welterfahrung und ästhetische Neugierde in Mittelalter und Früher Neuzeit, red. Klaus Krüger, Wallstein, 2002, ss. 147-177.

Dülmen, Richard van. Kultur und Alltag in der frühen Neuzeit: Das Haus und seine Menschen: 16. -18. Jahrhundert. C.H. Beck, 2005.

Eberlein, Johann Konrad. Apparitio regis - revelatio veritatis. Studien zur Darstellung des Vorhangs in der bildenden Kunst von der Spätantike bis zum Ende des Mittelalters. Reichert, 1982.

Falke, Jacob. Die deutsche Trachten- und Modewelt: Die Neuzeit. Ein Beitrag zur deutschen Kulturgeschichten. Vero Verlag, 2013.

Ferino-Pagden, Silvia. „La prima donna del mondo. Isabella d'Este Fiirstin und Mazenatin der Renaissance. Kunsthistorisches Museum, 1994.

Flasch, Kurt. Eva und Adam. Wandlungen eine Mythos. C.H.Beck, 2005

Frauke, Berndt, i Stephan Kammer. „Amphibolie - Ambiguität - Ambivalenz. Die Struktur antagonistisch-gleichzeitiger Stephan Zweiwertigkeit". Amphibolie - Ambiguität - Ambivalenz, red. Berndt Frauke i Stephan Kammer, Königshausen \& Neumnna, 2009, ss. 7-30.

Friedrich, Annegret. „Eros in Parisurtaildarstellungen in Früher Neuzeit”. Eros, Macht, Askese. Geslechterspannungen als Dialogstruktur, red. Helga Sciurie i Hans Jürgen Bachorski, Wissenchaftlicher Verlag Trier, 1996.

Fudge, Thomas A. „Incest and Lust in Luther's Marriage: Theology and Morality in Reformation Polemics". The Sixteenth Century Journal, t. 34, nr 2, 2009, nr 2: Marriage in Early Modern Europe, ss. 319-345.

Fumagalli. Edoardo. „Amore e Psiche in centri padani. A proposito del volgarizzamento di Boiardo", Fontes, t. 3, nr 5-6, 2000, ss. 73-82.

Gizowski, Mariusz. Herby patrycjatu gdańskiego. Wydawnictwo L\&L, 2000.

Grabińska, Teresa. „Miłość a przyjaźń w etyce Arystotelesa”. Fides et Ratio. Kwartalnik Naukowy, t. 3, nr 3, 2010, ss. 18-24.

Grabski, Józef. „'Victoria Amoris'. Titians's Venus of Urbino. A Commemorative Allegory of Martial Love". Artibus et Kistoriae, t. 20, nr 40, 1999, s. 9-33.

Grabski, Józef. The Significance of Shape and Colour. Essays on Art, Mostly of the Italian Renaissance. Bibliotheca Artibus et Historiae, 1999.

Grzybkowski, Andrzej. Między forma a znaczeniem. Studium z ikonografii, architektury i rzeźby gotyckiej. Wydawnictwo DiG, 1997.

Günther, Otto, i Karl Kleefeld K., Die Danziger Stadtbibliothek. Ihre Entwicklung und ihr Neubau. Druck von A.W. Kafemann, 1905.

Handwörtrebuch des Deutsche Aberglaubens, red. Eduard Hoffmann-Krayer i Hanns BächtoldStäubli, Bd. V, Walter De Gruyter \& Co. 1932/1933. 
Harasimowicz, Jan. „Der Danziger Maler Anton Möller als Bürger seiner Stadt und eifrieger Moralist im Geiste der lutherischen Reformorthodoxie". Art, Religion, Société dans l'espace germanique au XVI siècle, red. Frank Muller, Presses Universitaires de Strasbourg, 1997, ss. 77-105.

Harasimowicz, Jan. „Doctrina Doctrinarum. Katechetyczne i społeczno-obyczajowe treści dziesięciu Przykazań z Pruszcza Gdańskiego”. Porta Aurea. Rocznik Zakładu Historii Sztuki Uniwersytetu Gdańskiego, t. 2, 1993, ss. 55-99.

Hauber, Anton. Planetenkinderbilder und Sternbilder. Zur Geschichte des menschlichen. Glaubens und Irrens. Fachbuchverlag-Dresden, 1916.

Heckscher, William S. „The Anadyomene in the Mediaeval Tradition (Pelagia - Cleopatra Aphrodite): A Prelude to Botticelli's Birth of Venus". Nederlands Kunsthistorisch Jaarboek, vol. 7, 1956, ss. 1-38.

Heckscher, William S. "The Anadyomene in the Mediaeval Tradition.". Art and Literature. Studies in the Relationship, red. Egon Verheyen, Duke University Press, 1985, ss. 127-164.

Heinter, Helmut. „Die Fallhaube. Eine Erfindung des 16. Jahrhunderts?”. Medizinhistorisches Journal, t. 19, z. 3, 1984, ss. 273-276.

Hersch, Karen K. The Roman Wedding: Ritual and Meaning in Antiquity. Cambridge University Press, 2010.

Hoff, Ralf von den, Anna Schreurs-Morét, Christina Posselt-Kuhli, Hans W. Hubert i Felix Heinzer. „Zur Reichweite eines kulturellen Phänomens”. Imitatio heroica. Heldengleichung im Bildnis, red. Ralf von den Hoff, Felix Heinzer, Hans W. Hubert i Anna Schreurs-Morét, Ergon, 2015, ss. 9-33.

Ikonologie des Zwischenraums. Der Schleier als Medium und Metapher, red. Johannes Endres, Barbara Wittmann i Gerhard Wolf, Wilhelm Fink Verlag, 2005.

Impellusu, Lucia. Natura i jej symbole. Rośliny i zwierzęta, tłum. Hanna Cieśla, Arkady, 2006.

Insadowski, Henryk. Rzymskie prawo matzeńskie a chrześcijaństwo. Towarzystwo Naukowe KUL, 1935

Jongh, Edy de. „Pearls of Virtue and Pearls of Vice”. Simiolus, t. 8, nr 2, 1975/76, ss. 69-97.

Kalinowski, Lech. Speculum artis. Treści dzieła sztuki średniowiecza i renesansu, Wydawnictwo Naukowe PWN, 1989.

Karl Kühne. Kunst, Krieg und Hofkultur, red. Susan Martl, Till-Holgfer Borchert, Gabriele Keck. Katalog wystawy Historisches Museum Bern 25.04 - 24.08.2008; Bruggemuseum und Groeningenmuseum Brügge 27.03 - 21.07.2009, Belser, 2008.

Karpowicz, Mariusz. „Fontanna Neptuna i inspiracje weneckie w sztuce Gdańska”. Ludzie, kontakty, kultura XV i XVIII. Prace ofiarowane profesor Marii Boguckiej, red. Jerzy Kowecki i Janusz Tazbir, Wydawnictwo Naukowe Semper, 1997.

Kathke, Petra. Porträt und Accessorie. Eine Bildniform im 16. Jahrhundert. Reimer Verlag, 1997.

Kaulbach, Hans-Martin, i Schleier Reinhart. „Der Welt Lauf”. Allegorische Graphikserien des Manierismus. Katalog wystawy Staatsgalerie Stuttgart, Kunstgesichtliches Institut der RuhrUniversität Bochum, Staatsgalerie Stuttgart, 1997.

Kizik, Edmund. „Ubiory gdańskich mieszczek w drugiej połowie XVI i w pierwszej połowie XVII w." Rocznik Gdański, t. 67-68, 2007- 2008, ss. 17-31.

Kizik, Edmund. Wesele, kilka chrztów i pogrzebów. Uroczystości rodzinne w mieście hanzeatyckim od XVI do XVIII wieku. Officina Ferberiana, 2001. 
Klauser. Theodor. „Baldachin”. Reallexikon für Antike und Christentum, I, 1950, szp. 1150-1153.

Klimkiewicz. Anna. ,Hypnerotomachia Poliphili” Francesca Colonny, Wydawnictwo Uniwersytetu Jagiellońskiego, 2015.

Kobielus, Stanisław. „Węzły w sztuce średniowiecza i ich znaczenie”. Fides ex visu. U drzwi twoich, red. Ryszard Knapiński i Aneta Kramiszewska, Wydawnictwo Werset, 2013, ss. 219-236.

Kohlenberger, Helmut K. „Art. Ambiguität (Amphibolie)”. Historisches Wörterbuch der Philosophie, red. Joachim Ritter i Karlfried Gründer, t. 1, Schwabe, 1972, ss. 802-806.

Köhler, Karl. Die Entwickelung der Tracht in Deutschland während des Mittelalters, Bd. 1, Nürnberg, Heerdegen, 1877.

König, Ingemar. Vita Romana. Konrad Theiss, 2004.

Koos, Marianne. „Dosso's Ambiguity”. Renaissance Love. Eros, Passion, and Friendship in Italian Art. around 1500. Italienische Forschungen des Kunsthistorischen Institutes in Florenz, I Mandorli, red. Jeanette Kohl, Marianne Koss i Adrian W.B. Randolph, Deutscher Kunstverlag, 2014, ss. 45-65.

Krüger, Klaus. Das Bild als Schleier des Unsichtbaren: Ästhetische Illusion in der Kunst der frühen Neuzeit in Italien. Wilhelm Fink Verlag, 2001.

Lorenzo Lotto Portraits, red. Enrico Maria dal Pozzolo i Miguel Falomir, współpraca Matthias Wivel. Katalog wystawy 19.06 - 30.09.2018 Madrid, Museo Nacional del Prado, 2018.

Mączak, Antoni. Życie codzienne w podróżach po Europie w XVI i XVII wieku. Państwowy Instytut Wydawniczy. 1984.

Maniera: Pontormo, Bronzino und das Florenz der Medici, red. Bastian Eclercy, Prestel Verlag, 2016.

Meininghaus, Heiner. „Muskattreiben und Pomander für edle Gewürze”. Weltkunst, t. 14-15, nr 71, 2001, s. 2220-2221.

Mielnik, Magdalena. „Pasja poznawania. Orientalny album Bartholomäusa Schachmana w kontekście rozwoju geografii w XVI wieku". Sztuka podróży. Bartholomäus Schachmann: 1559-1614. Muzeum Narodowe w Gdańsku, 2012.

Mielnik, Magdalena. „Stateczne matrony i cnotliwe panny, czyli Księga ubiorów gdańskich Antona Möllera w kontekście europejskiej tradycji Trachtenbüchern”, Quart, nr 3 (9), 2008, ss. 20-40.

Mikocki, Tomasz. Zgodna, pobożna płodna, skromna piękna... Propaganda cnót żeńskich w sztuce rzymskiej. Leopoldinum, 1997.

Mirimonde Albert P. de. Astrologie et Musique. Editions Minkoff, 1977.

Miziołek, Jerzy. „Historia Psyche i Primavera Sandra Botticellego. O obrazach z kolekcji Karola Lanckorońskiego w Galerii Berlińskiej i zbiorach Abegg Stiftung”. Rocznik Historii Sztuki, t. 28, 2013, ss. 48-80.

Mossakowski, Stanisław. „Proweniencja artystyczna twórczości Bartłomieja Berrecciego w świetle dekoracji kaplicy Zygmuntowskiej”. Biuletyn Historii Sztuki, t. 47, nr 2-4, 1986, ss. $165-214$.

Musacchio, Jacqueline Marie. The Art and Ritual of Childbirth in Renaissance Italy. Yale University Press, 1999.

Musacchio, Jacquline Marie. Art, Marriage, and Family in Florentine Renaissance Palace. Yale University Press, 2010, ss. 136-159. 
Nalezyty, Susan. Pietro Bembo and the Intelectual pleasures of a Renaissance writer and Art Collector. Yale University Press, 2017.

Nevitt H. R. Junior. Art and the Culture of Love in the seventeenth-Century Holland. Cambridge University Press, 2003.

Nützmann, Hannelore. „Verschchüsselt in Details. Hochzeitbilder für Lorenzo de’ Medici”. Jahrbuch Preussischer Kulturbesitz, nr 34, 1998, ss. 223-235.

Nützmann, Hannelore. Alltag und Feste. Florentinische Cassone- und Spallieramalerei aus der Zeit Botticellis, Berlin (Staatliche Museen Preussischer Kulturbesitz). Gemäldergalerie Berlin, 2000.

Orchard, Karin. Androgynität in der Kunst des 15 und 16 Jahrhunderts. Thesis dissertation, Hamburg, 1986.

Orchard, Karin. Annäherungen der Geschlechter: Androgynie in der Kunst des Cinquecento. Kunstgeschichte, t. 10. LIT Verlag, 1992.

Patrizer, Bürger, Einwohner der Freien und Hansestadt Danzig in Stamm- und Namentafeln vom 18. Jahrhundert, red. Dorothea Weichbrodt, Danziger Verlangsgesellschaft, T. 1, Schwentine Rosenberg, 1988.

Podbielkowski, Zbigniew. Stownik roślin użytkowych. Państwowe Wydawnictwo Rolnicze i Leśne, 1989.

Randalph, Adrian W.B. Engaging Symbols: Gender, Politics, and Public Art in Fifteenth-Century Florence. Yale University Press, 2002.

Rembowska, Irena. „Ubiory bogatych mieszczan gdańskich w XVII i XVIII wieku na podstawie przepisów przeciwko zbytkowi i spisów testamentowych". Zeszyty Naukowe Wydziału Humanistycznego Uniwersytetu Gdańskiego, nr 10, 1980, Historia, ss. 49-72.

Renaissance Love. Eros, Passion, and Friendship in Italian Art. around 1500, Italienische Forschungen des Kunsthistorischen Institutes in Florenz, I Mandorli, red. Jeanette Kohl, Marianne Koss i Adrian W.B. Randolph, Deutscher Kunstverlag, 2014.

Schaumann, Elly. „Beiträge zu einer Geschichte der Tracht in Danzig”. Zeitschrift des Westpreussichen Geschichtsvereins, z. 73, 1937, ss. 28-33.

Schramm, Percy F. Herrschaftszeichen und Staatssymbolik. Beiträge zu ihrer Geschichte vom dritten bis zum sechzehnten Jahrhundert. Hiersemann, 1956.

Sluiter, Eric Jan. Seductress of Sight. Studies in Deutsch art of the Golden Age. W Books, 2001

Strauss, Heinz Artur. „Zur Sinndeutung der Planetkinderbilder”. Münchner Jahrbuch der bildenden Kunst, t. 2, 1925, ss. 48-54.

Talvacchia, Bette. Taking positions. On the Erotic in Renaissance Culture. Princeton University Press, 1999.

Transalpinum. Od Giorgiona i Dürera do Tycjana i Rubensa. Dzieła malarstwa europejskiego ze zbiorów Kunsthistorisches Museum w Wiedniu, Muzeum Narodowego w Warszawie i Muzeum Narodowego w Gdańsku. Katalog wystawy, Muzeum Narodowe w Warszawie 18 września - 10 grudnia 2004 i Muzeum Narodowe w Gdańsku, 20 grudnia 2004 20 lutego 2005, red. Dorota Folga i Antoni Ziemba, Bosz, 2004.

Turner, James Grantham. Eros Visible. Art, Sexuality and Antiquity in Renaissance Italy. Yale University Press, 2017.

Ullrich, Wolfgang, i Stephan Meier-Oeser. „Art. Zweideutigkeit; Vieldeutigkeit”. Historisches Wörterbuch der Philosophie, red. Joachim Ritter i Karlfried Gründer, t. 12, Schwabe 2005, s. 1514-1519.

Wilhelm II. Ursprung und Anwendung des Baldachins. A. de Lange, 1939. 
Witte, Birgit. „Raffael und das Bildnis der Ehefrau. Liebessemantik und Equalitas in der Porträitmalerei des 16. Jahrhunderts". Doris Guth i Elisabeth Priedl. Bilder der Liebe. Liebe, Begehren und Geschlechterverhältnisse in der Kunst der Frühen Neuzeit. Transcript, 2012, ss. 73-76.

Zdrenka, Joachim. Rats- und Gerichtspatriziat der Rechten Stadt Danzig. 1526-1792, t. II, Verein für Familienforschung in Ost- und Westpreussen, 1989.

Żygulski, Zdzisław Jun. „, Stary Gdańsk jako forma muzealna”. Porta Aurea, Rocznik Zakładu Historii Sztuki, t. 3, 1994, ss. 7-13.

Żygulski, Zdzisław Jun. „Ze studiów nad damą z gronostajem. Styl ubioru i węzły Leonarda”, Biuletyn Historii Sztuki, t. 31, nr 1, 1969, ss. 8-40.

\section{METAFORY MIŁOŚCI \\ W PORTRECIE PATRYCJUSZKI GDAŃSKIEJ ANTONA MÖLLERA}

Streszczenie

Portret patrycjuszki gdańskiej, przypisywany Antonowi Möllerowi Starszemu (ok. 1563-1611), budzi do dziś spory atrybucyjne, nie ustalono także tożsamości portretowanej. Obraz posiada interesującą ikonografię, wskazującą na inspiracje sztuką włoską i funkcjonującymi w niej metaforami różnych aspektów miłości. Na Portrecie patrycjuszki gdańskiej była pierwotnie przedstawiona kotara zaopatrzona w dwa węzły. Ujawniła to fotografia w świetle podczerwonym. Ten ikonograficzny szczegół nie został zauważony przez badaczy. Nie interesowano się nim w semantyce portretu, wystąpił jednak w siedmiu zachowanych do dziś, a malowanych przez Antona Möllera i jego warsztat portretach kobiet, mężczyzn i dzieci. Artykuł poddaje analizie Portret patrycjuszki gdańskiej z uwzględnieniem zastosowanych w nim motywów, atrybutów i ubioru. Jest to przyczynek do badań nad portretem prywatnym, który obowiązywał w Gdańsku pod wpływem mody panującej w XVI wieku w malarstwie europejskim, nawiązującym do włoskiego arystokratycznego portretu kobiet. Analiza konterfektu zwraca uwagę, że ta praca w swojej stylistyce wykazuje wpływ malarstwa niderlandzko-niemieckiego, natomiast w ikonografii rozwija model obrazowy zaczerpnięty z tradycji malarstwa i grafiki włoskiej (Florencja i Wenecja). Jest także próbą identyfikacji portretowanej jako żony Johanna Speymanna, Marii Judity z Bahrów.

Słowa kluczowe: malarstwo gdańskie ok. 1600 r.; portret; Anton Möller; Herman Han; sztuka włoska XVI wieku; ikonografia miłości; kotara z węzłem.

\section{THE METAPHORS OF LOVE \\ IN ANTON MÖLLER'S PORTRAIT OF A GDAŃSK FEMALE PATRICIAN}

\section{Su m mary}

The Portrait of a Gdańsk Patrician, attributed to Anton Möller the Elder (c. 1563-1611), is still giving rise to discussion, and the identity of the lady portrayed has still not been established. The painting has an interesting iconography, illustrating both the Italian art that inspired it and the metaphors of various aspects of love present within it. The Portrait of a Gdańsk Patrician originally depicted a curtain with two knots, as revealed by IR photography. This iconographic detail has been overlooked by researchers, but it appears in seven portraits of other men, women and children painted by Anton Möller and his workshop and which have survived to this day. The 
article examines the Portrait, considering the motifs, attributes and clothing used in it. It is thus an introduction to the study of private portrait paintings which was in vogue in Gdańsk under the influence of the 16th century fashion in European painting, drawing on Italian aristocratic portraits of women. As the analysis of the portrait shows, the style of this work shows the influence of Dutch-German painting, while, from the point of view of iconography, it develops the pictorial model drawn from the tradition of Italian painting and graphics (Florence and Venice). This article also attempts to identify the woman portrayed as Maria Judita née Bahr, the wife of Johann Speymann.

Keywords: Gdańsk painting around 1600; portrait; Anton Möller; Herman Han; Italian art in the 16th century; iconography of love; curtain with a knot. 
1a. Anton Möller (?), Portret patrycjuszki gdańskiej, ok. 1599,

Gdańsk, Muzeum Narodowe

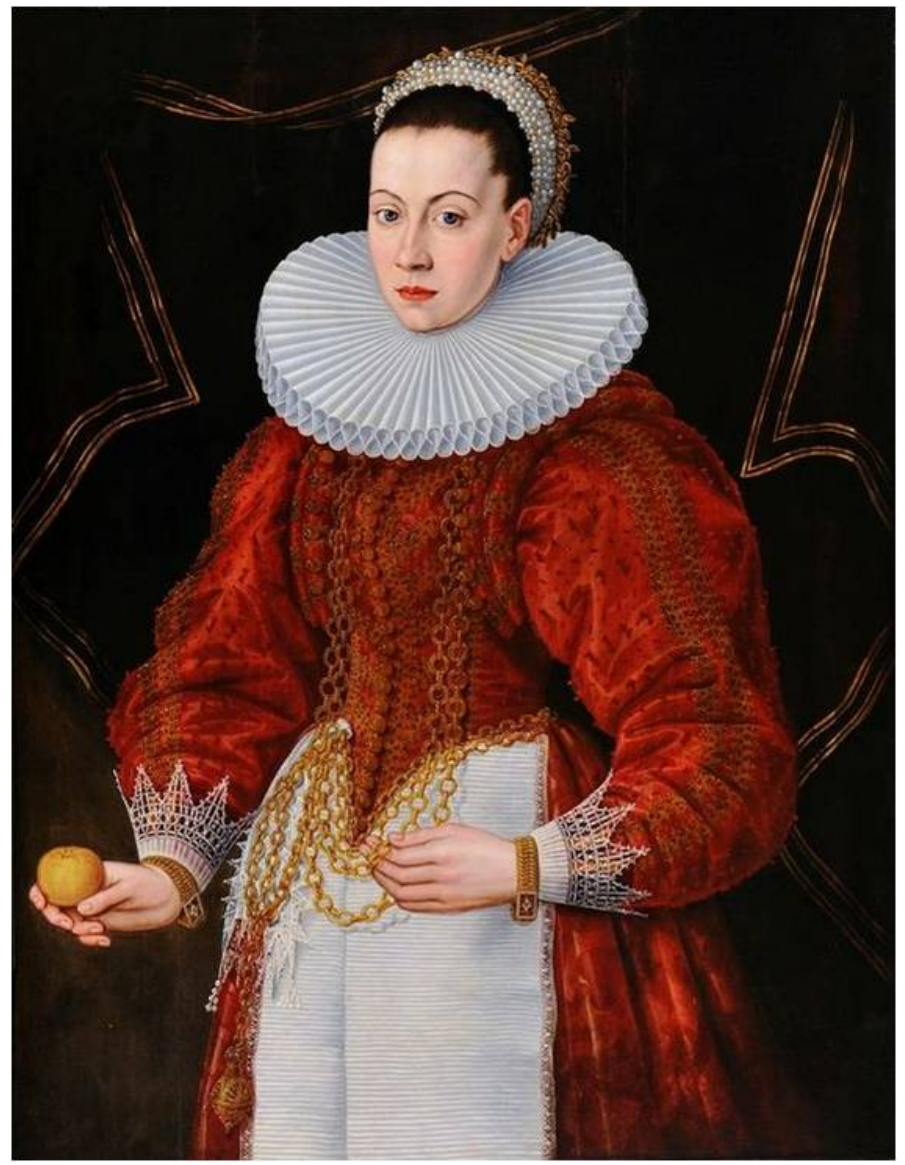

1aa. Herb rodziny Speymann

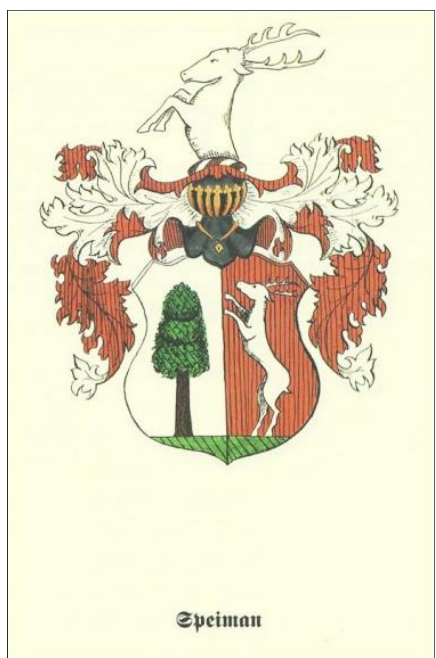




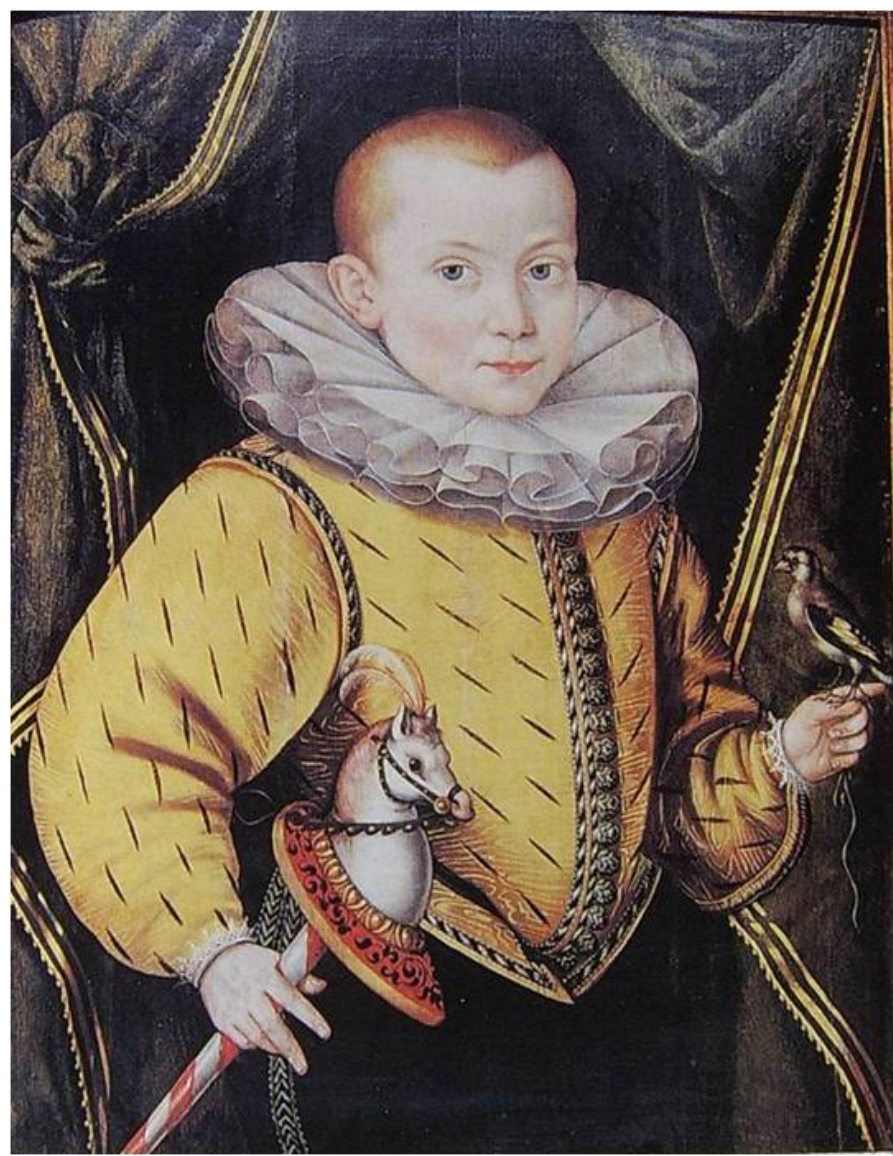

1b. Anton Möller (?), Portret chtopca ze szczygtem i drewnianym konikiem,

Pszczyna Muzeum Wnętrz Zabytkowych, Muzeum w Gliwicach

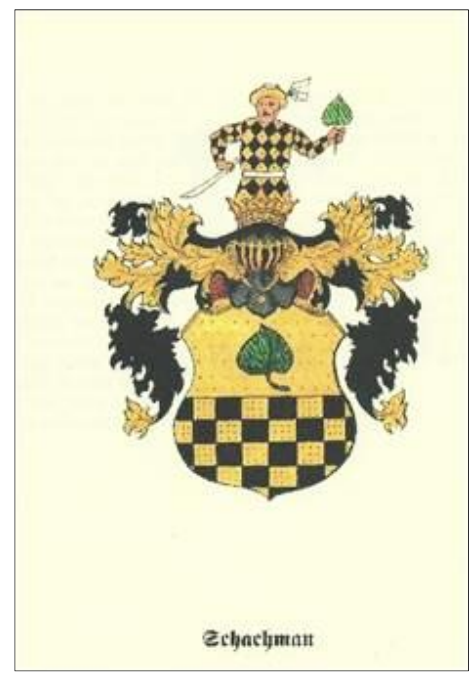

1bb. Herb rodziny Schachmann 


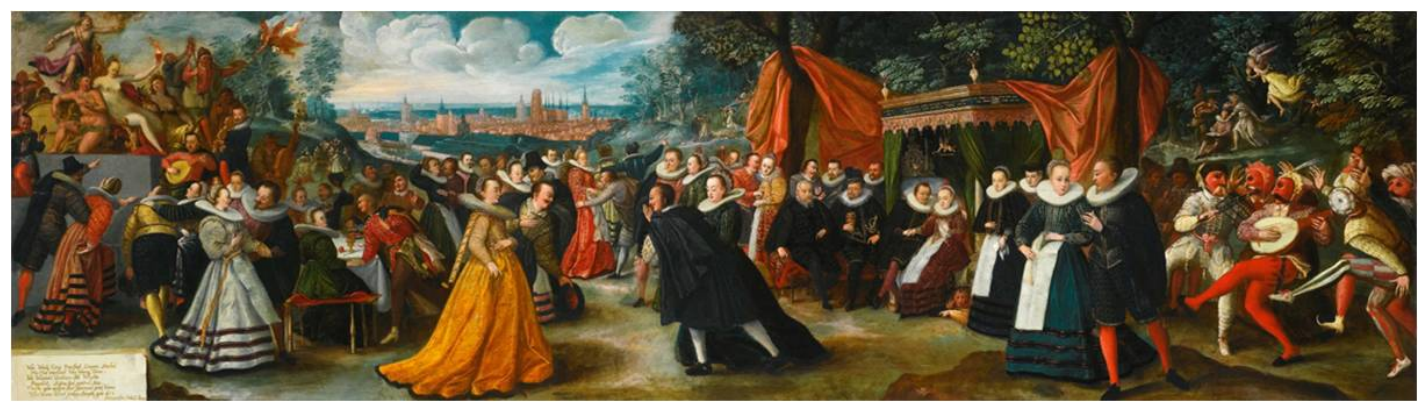

2a. Anton Möller (?), Alegoria mitości (Wenus i jej Dzieci), ok. 1600, dawniej Gallerie Lingebauer, Düsseldorf

2b. Jan Saenredam według Goltziusa, Wenus i jej dzieci, ok. 1596, miedzioryt

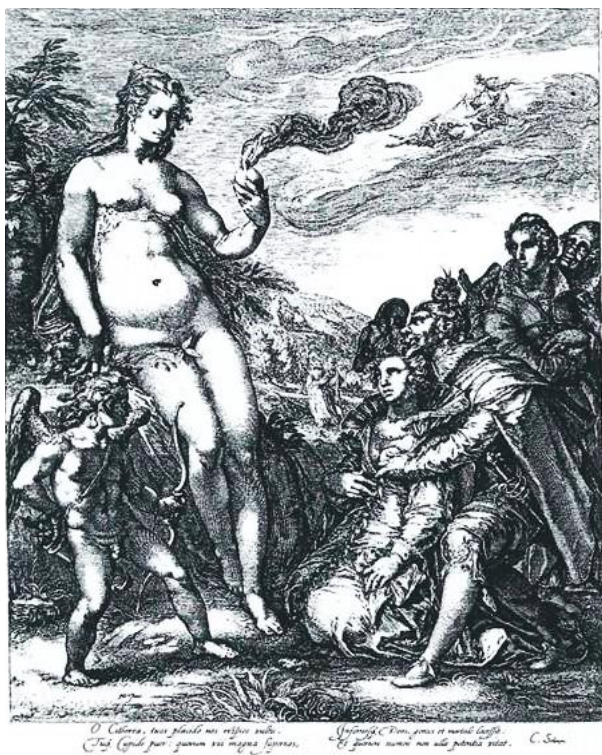

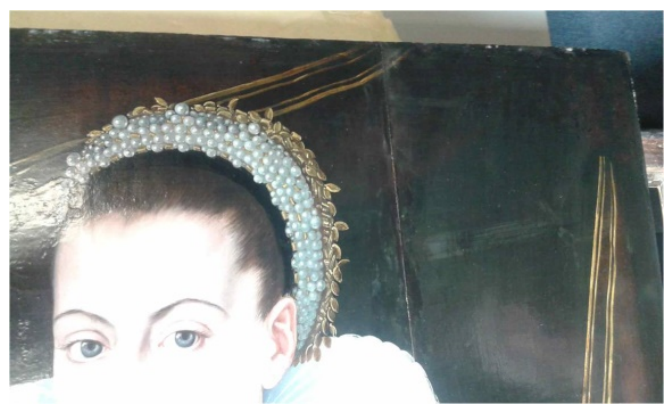

3a. Anton Möller, Portret patrycjuszki gdańskiej, ok. 1599, Gdańsk, Muzeum Narodowe, fotografia w świetle białym

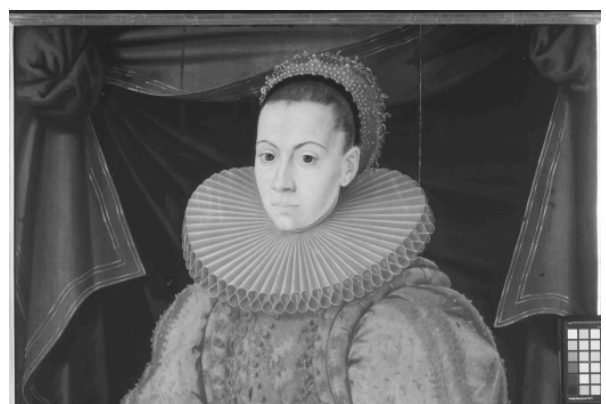

3b. Anton Möller, Portret patrycjuszki gdańskiej, ok. 1599, Gdańsk, Muzeum Narodowe, fotografia w podczerwieni G. Nosorowski. 


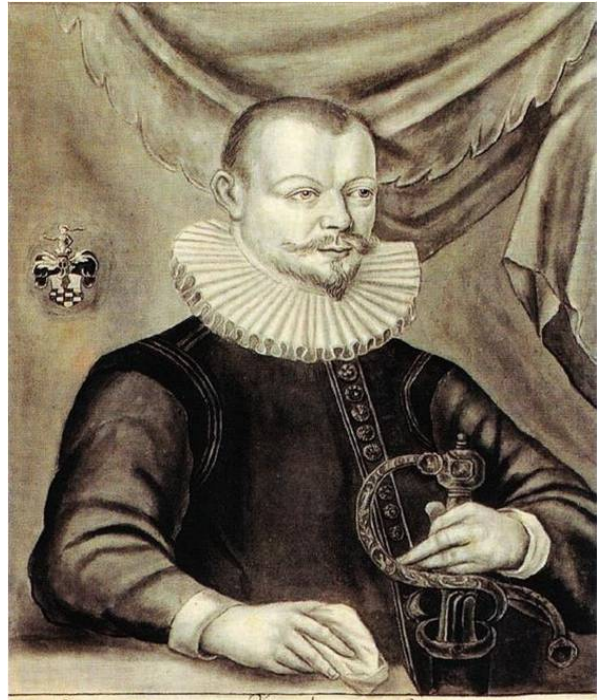

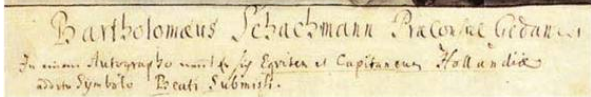

4a. Anton Möller, Portret Barttomieja Schachmanna, ok., 1606, Gdańsk, Biblioteka Gdańska PAN

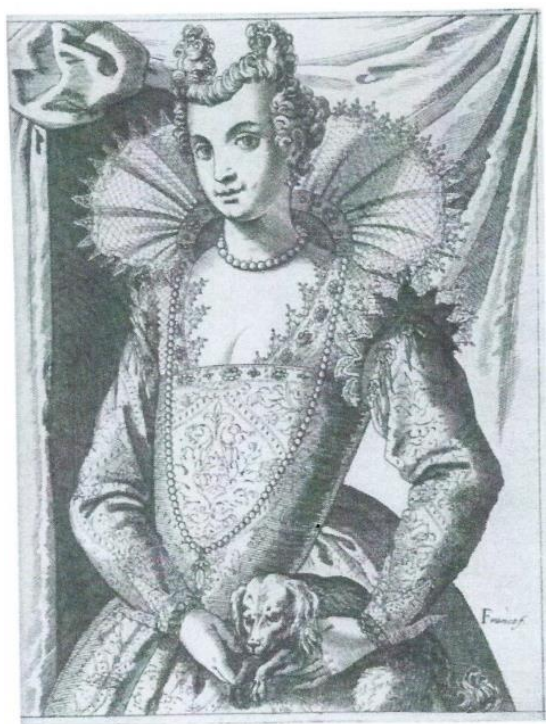

5a. Dama z pieskiem, G. Franco, Habiti delle donne venetiane, Wenecja, ok. 1591-1609, The Metropolitan Museum of Art

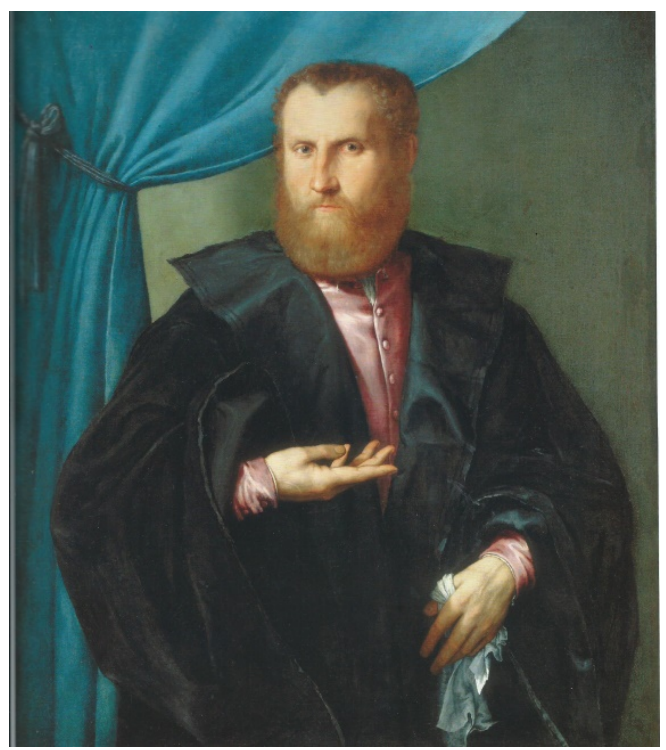

4b. Lorenzo Lotto, Portret mężczyzny z broda, 1542-1544, Nowy Orlean,

New Orelans Museum of Art

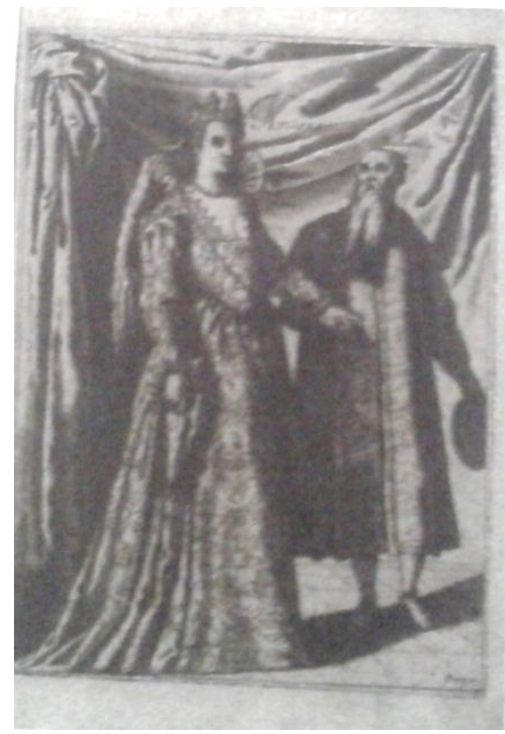

5b. Prezentacja panny młodej pod baldachimem przez ojca lub opiekuna, G. Franco, Habiti delle donne venetiane, Wenecja, ok. 1591-1609, The Metropolitan Museum of Art 


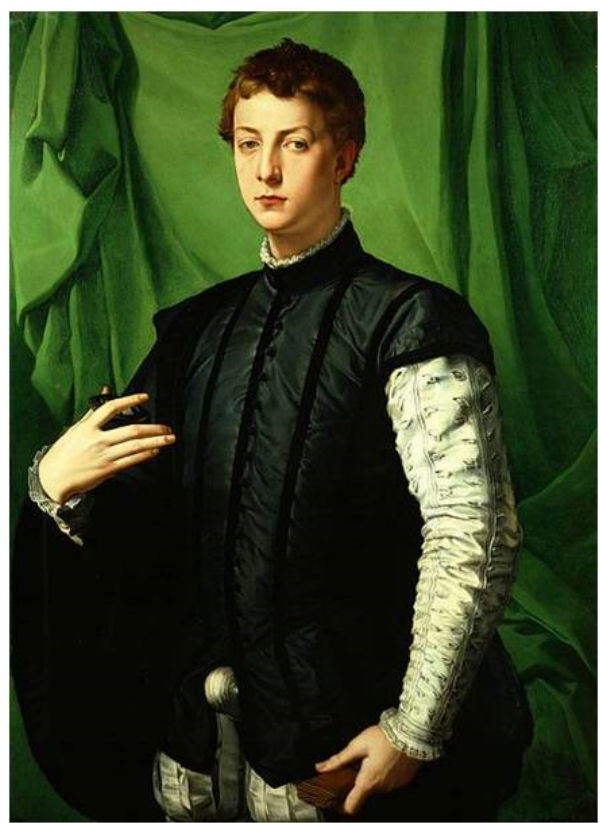

6a. Angolo di Cosimo Bronzino, Portret Ludovico Capponi, 1550-55, New York, kolekcja Frick

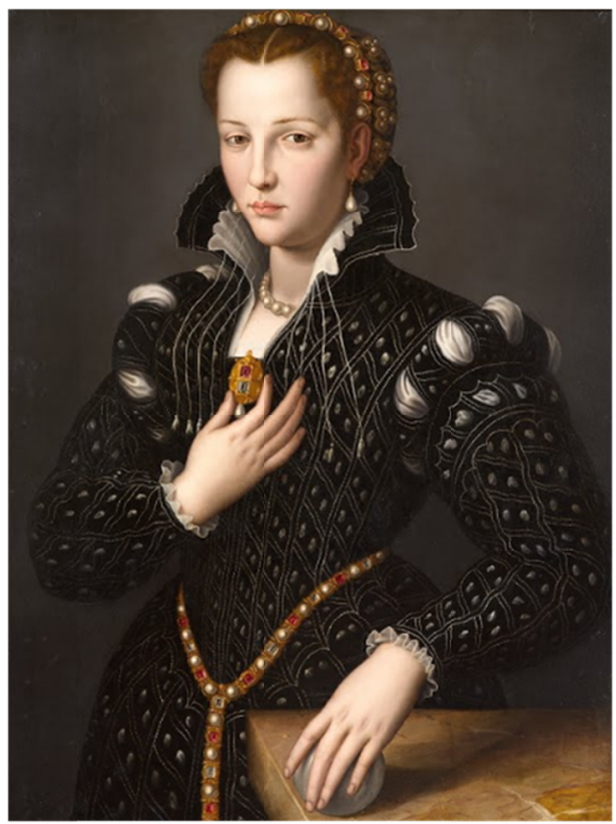

6b. Alessandro Allori (ok. 1545-1561), Portret Lukrecji de Medici, 1560, The North Carolina Museum

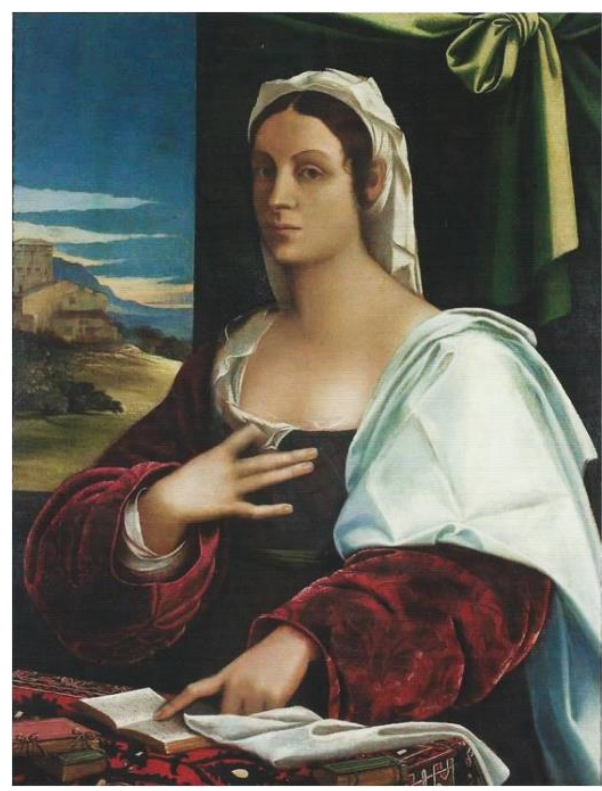

6c. Sebastiano del Piombo, Portret Vittoria Collona, Museu Nacional d'Art de Catalunya 


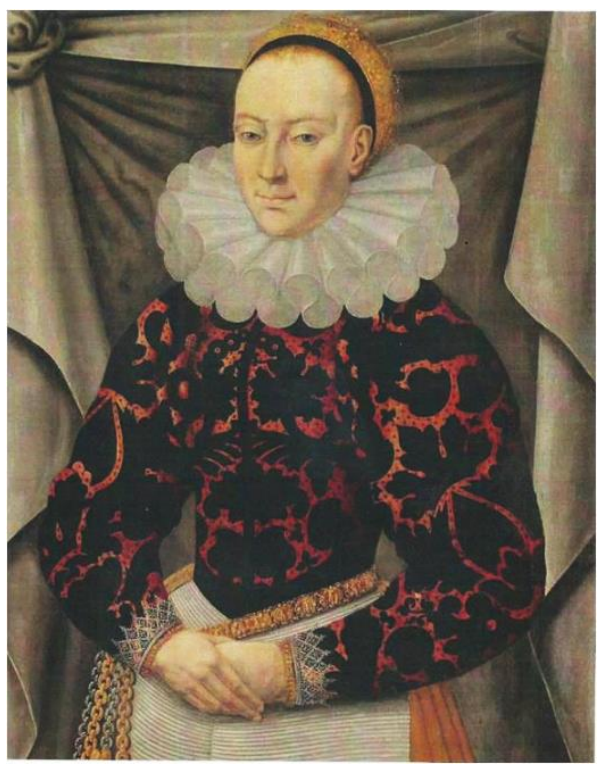

7a. Anton Möller, Portret patrycjuszki, ok. 1590, Kolonia, niemiecka kolekcja prywatna

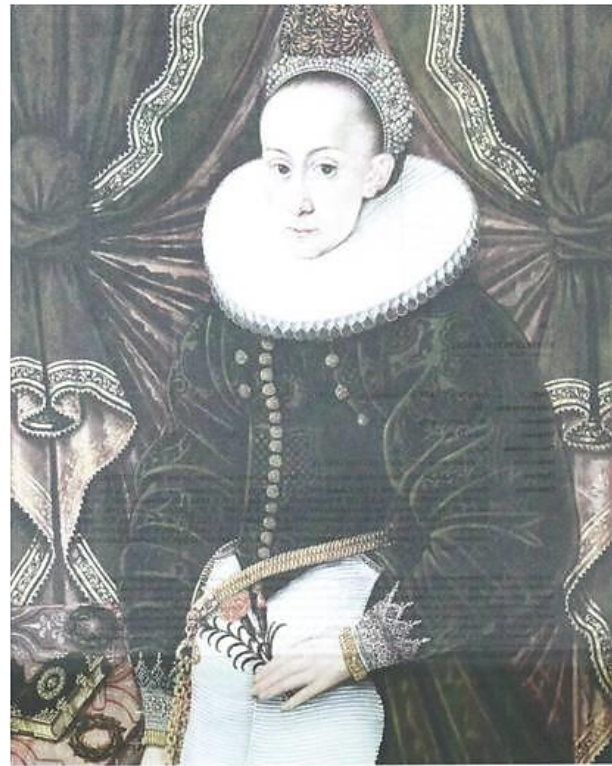

7c. Anton Möller warsztat, Portret patrycjuszki, ok. 1590-1600, Muzeum Narodowe Finlandii

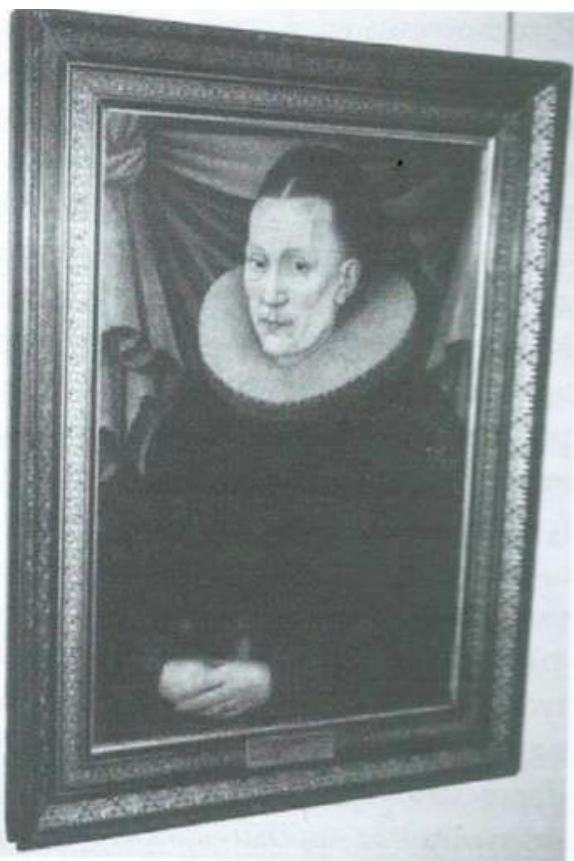

7b. Anton Möller, Portret starszej patrycjuszki, ok. 1600, Lwowska Galeria Obrazów

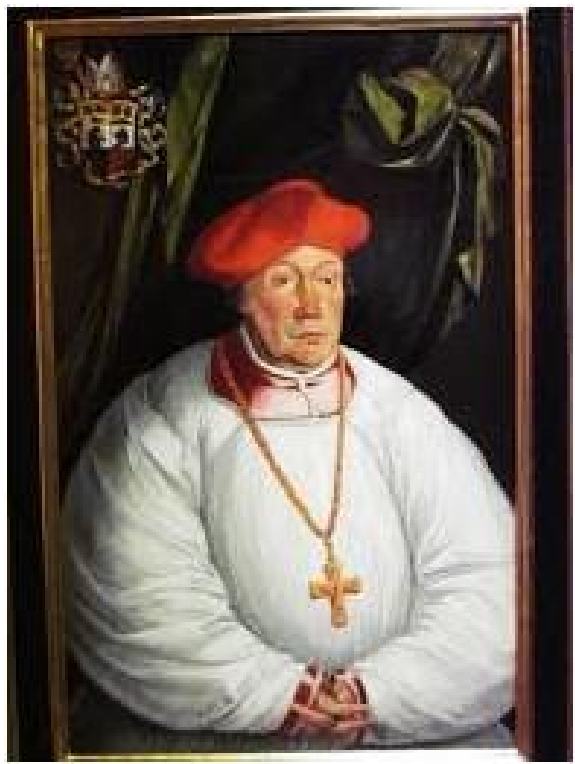

7d. Portret biskupa Moritza Ferbera, ok. 1590 , olej, deska, sygn. AM. 1590 - kopia z obrazu Crispina Herranta autoryzowana przez Möllera 


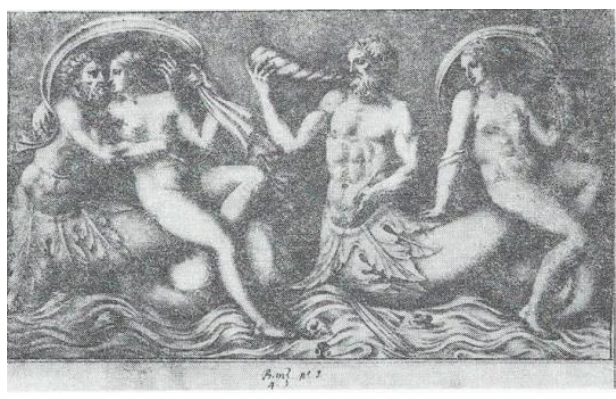

8a. Rzymski sarkofag, ukazany na rysunku Bernardina Ciferri, Biblioteka Eton College,

Topham Collection, sygn.. B.m. 4.1
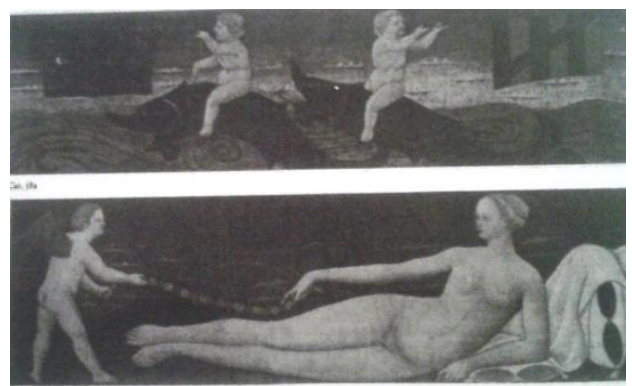

8b. Wenus z Amorem, Cassone, Toskania

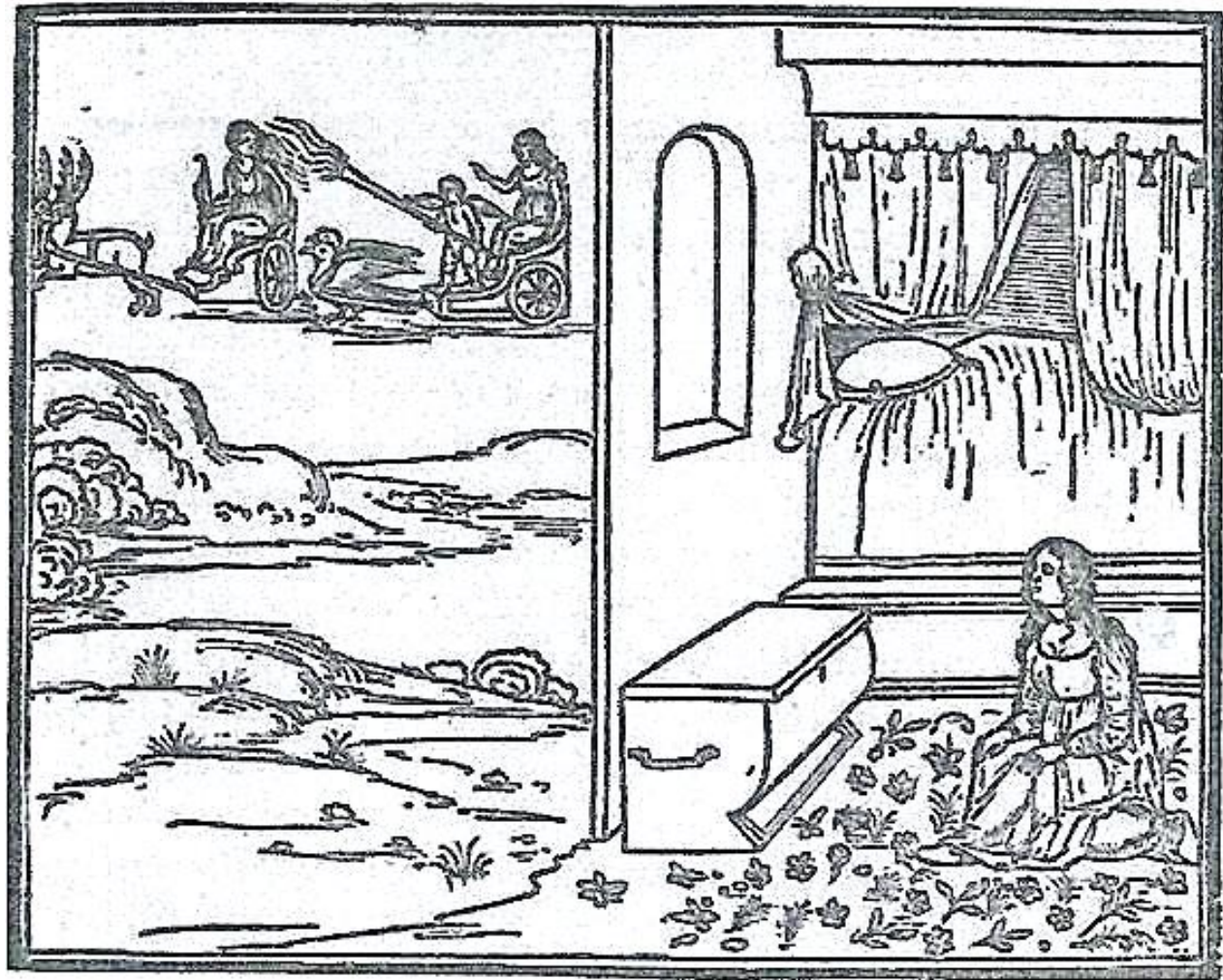

8c. Oblubienica, ilustracja do Hypnerotomachi Poliphili, wydanego w Wenecji (1499, Aldius Manutius), New York, The Metropolitan Museum of Art 


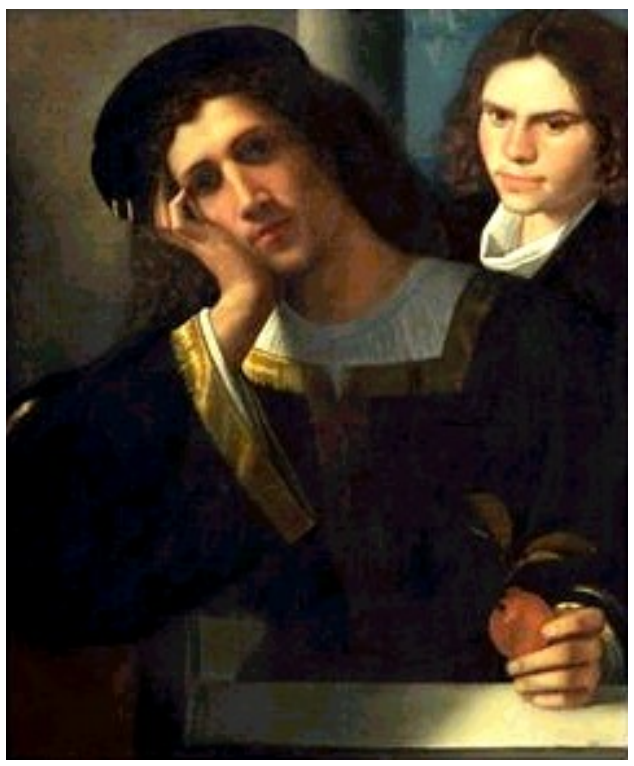

9a. Krąg Giorgione, Portret podwójny Ludovisi, 1512-1513, Palazzo Venezia

ALCIATIEMBLEN。 Malus micdica.

EMBLEMA C CVI.

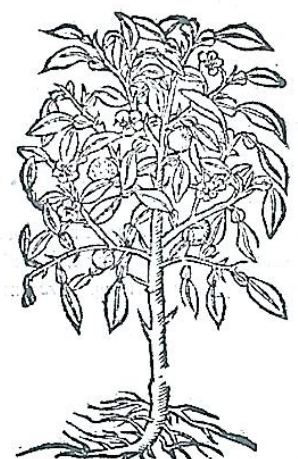

Auted funt Veneris poma hec:iucundus amaror

Indicat, eft Grecisfic j $\lambda u x$ ú 7 bxpos anior.

$A$ Eminimus huius emblematis in amoris

9c. Złote jabłko (malus medica), Andrea Alciati, Emblemata, 1548

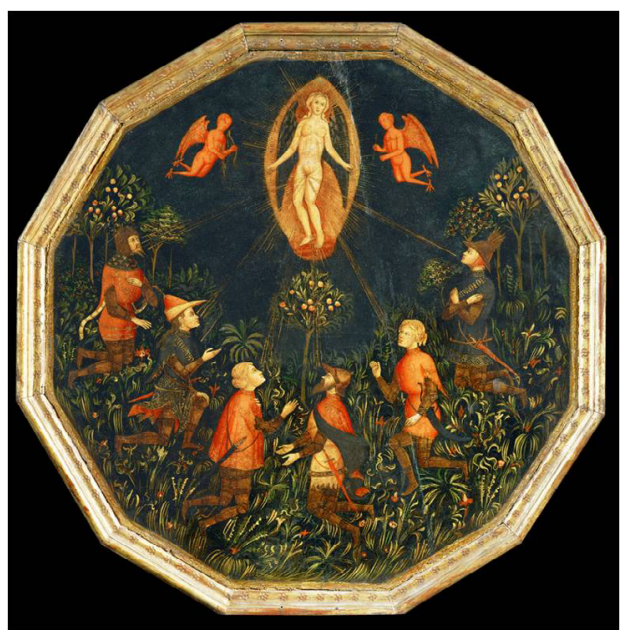

9b. Triumf Venus, taca urodzinowa, Mistrz Charles of Durazzo (Francesco di Michaele?), ok. 1400, Paryż, Luwr, nr. inw. Diameter: 51 cm R.F.2089

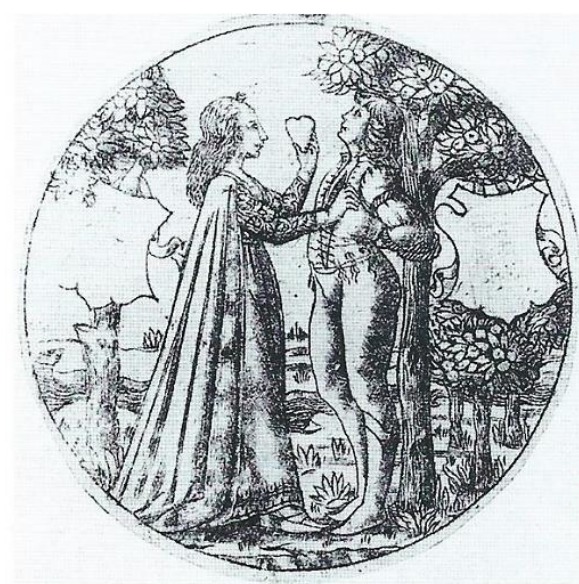

12. Baccio Baldini, attributed to, The Cruelty of Love, ca. 1470. Engraving, diameter $10.1 \mathrm{~cm}$. London: British Museum.

9d. Baccio Baldini, Młodzieniec przywiązany do drzewa pomarańczoweg, 1496, Londyn, British Museum 


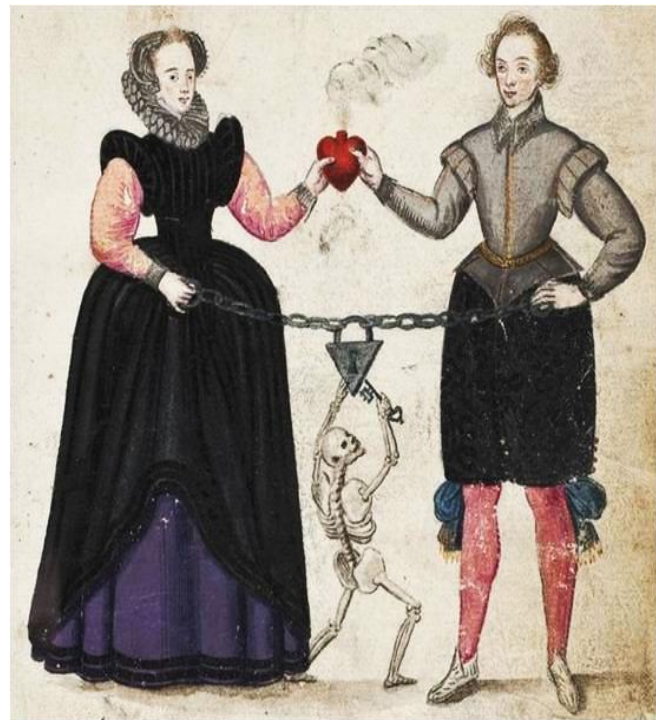

10b. Motyw łańcucha zamkniętego kluczem z kłódką, k. XVI w Album Amicorum 10c. Agnolo Bronzino Alegoria Wenus z Kupidynem, 1540-1545, Londyn, National Gallery

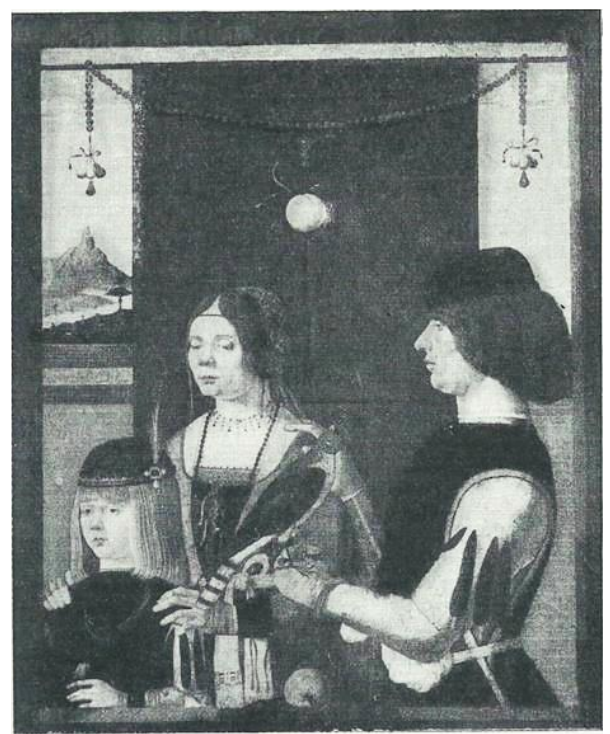

10a. Baltasare Estense, Portret Rodziny, Monachium, Baierische Staatsgemäldesammlung

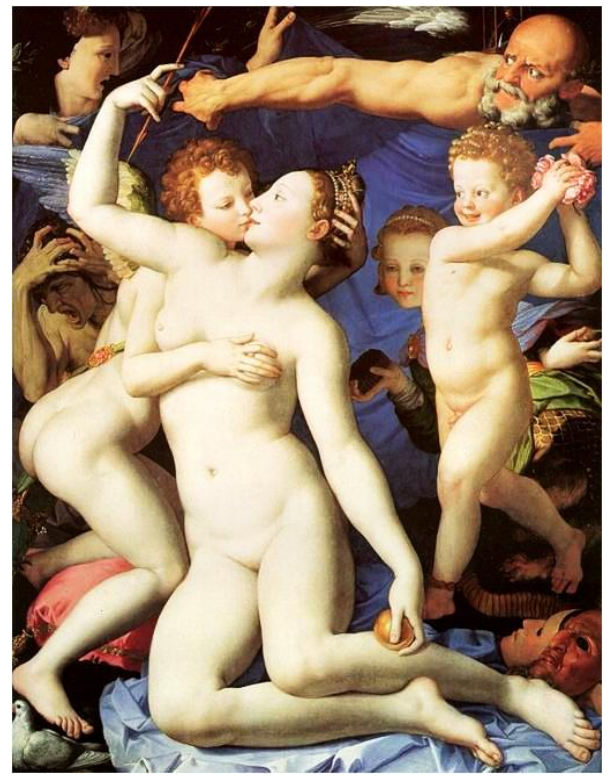

